DARIUSZ ŁUKASIEWICZ

Instytut Historii PAN, Poznań

\title{
Z DZIEJÓW POLITYKI SANITARNEJ POD PRUSKIM ZABOREM $1772-1807$
}

\author{
Splot modernizacyjny
}

Absolutyzm w Prusach przyniósł, już poczynając od doby rządów Wielkiego Elektora Fryderyka Wilhelma, gwałtowne przyśpieszenie rozwoju nowoczesnych instytucji państwa. Ze względów militarnych zaczęło ono szybko interesować się zdrowiem mieszkańców, ich kondycją biologiczną i demografią ${ }^{1}$. Modernizację spowalniał jednakże ciężar wydatków militarnych i bardziej nasilona niż gdzie indziej rola militaryz$\mathrm{mu} \mathrm{w}$ systemie społeczno-ekonomicznym niewielkiego kraju. Elitą kraju była szlachta, ale tutaj przede wszystkim na stanowiskach oficerskich, a relacja pan-poddany powielana była dosłownie w zależności dowódca-żołnierze. Uzasadnionych krytyk modernizacji pruskiej nie brakuje i wiele tam uwag słusznych. Najpierw Adelheid Simsch i Wolfgang Neugebauer oceniali krytycznie rezultaty modernizacji pruskiej w ogóle i w Prusach Południowych, Neugebauer wskazywał na papierową rzeczywistość edyktów, Simsch zaś akcentowała dominację pozbawionej dłuższej perspektywy polityki oraz dominację wydatków na cele militarne ${ }^{2}$. Potem Hans-Jürgen Bömelburg pisał, że ważnym momentem obcości i wrogości między Prusami i Polską była mentalna różnica

\footnotetext{
${ }^{1}$ N. Paul, Zum Zwecke der Verpflegung dürftiger Kranker, w: „Einem jeden Kranken in einem Hospitale sein eigenes Bett”. Zur Sozialgeschichte des Allgemeinen Krankenhauses in Deutschland im 19. Jahrhundert, red. A. Labisch, R. Spree, Frankfurt-New York 1996, s. 93-94; D. Łukasiewicz, Modernizacja przed modernizacją. Próby reform cywilizacyjnych $w$ Prusach Południowych w latach 1793-1806, „Studia Historica Slavo-Germanica” 26, 2004/2005 (wyd. 2006), s. 41-78.

${ }^{2}$ A. Simsch, Die Wirtschaftspolitik des preußischen Staates in der Provinz Südpreussen 1793-1806/7, Berlin 1984; W. Neugebauer, Absolutistischer Staat und Schulwirklichkeit in Brandenburg-Preussen, Berlin-New York 1985.
} 
między centralistycznym, biurokratycznym Militärstaat a federacyjnym i stanowym społeczeństwem szlacheckim oraz że modernizacja pruska w Prusach Zachodnich właściwie się nie powiodła. Ważne jednak, żeby rozumieć różnicę między procesem modernizacyjnym, który został zapoczątkowany, a doraźnymi, często słusznie wskazywanymi, słabościami rządów pruskich, wynikającymi nie z nadmiernej biurokracji, ale ze zbyt słabych instytucji państwowych, które w XVIII w. były dopiero w powijakach, jak również z korupcji lub innych przyczyn. Także personel urzędniczy i policyjny państwa pruskiego był niezwykle skromny. Znamienne też, że wspomniane prace pisane były z dosyć neoliberalnej perspektywy, uwzględniając gospodarkę, handel i fiskalizm, a także - z wyjątkiem książek Neugebauera - prawie nie odnoszą się one do modernizacji instytucjonalnej, która miała w okresie oświecenia kluczowe znaczenie (prawodawstwo, biurokracja, szkolnictwo, nauka, zdrowie, ubezpieczenia) ${ }^{3}$. Sprawy kluczowe dla negatywnego oddziaływania Prus na dzieje Polski są u nas już w znacznym stopniu znane, natomiast mniej znana twórcza, modernizacyjna rola państwa pruskiego ${ }^{4}$. W Polsce używa się ostatnio pojęcia samomodernizacji, dla ukazania twórczej roli ludności polskiej w rozwijaniu kraju. Jak pisze słusznie Lech Trzeciakowski: „W zaborze pruskim istniały warunki specyficzne. Prusy prowadziły politykę germanizacyjną. $Z$ drugiej jednak strony, dążąc konsekwentnie do modernizacji państwa, stworzyły warunki dla różnych form aktywności społecznej. [--] Władze były zainteresowane wzrostem cywilizacyjnym tych terytoriów", jednak stanowiąca połowę ludność niemiecka była niesłychanie faworyzowana ${ }^{5}$.

Nie będę powielał i referował znanych już cieniów modernizacji, ale skupię się na procesach tworzenia nowych instytucji zdrowotnych przede wszystkim w Prusach Południowych i Zachodnich na przełomie XVIII i XIX w. ${ }^{6}$ Jak wiadomo, medycyna naukowa tego czasu, podobnie jak szkolnictwo i in., była jeszcze bardzo niedoskonała. Jan Jakub Rousseau nie bez racji mówił z perspektywy zdrowia ówczesnego pacjenta, że byłoby lepiej, gdyby lekarzy wcale nie było. Kiedy dżuma w XVIII w. ustąpiła z Europy, nadal nie znano prawdziwego sposobu zarażania się i mechanizmów choroby i tak było aż do końca XIX w., kiedy odkryto bakterie

${ }^{3}$ H.-J. Bömelburg, Zwischen polnischer Standesgesellschaft und preussischem Obrigkeitsstaat. Vom königlichen Preussen zu Westpreussen (1756-1806), München 1995, s. 208-209.

${ }^{4}$ A. Simsch, op. cit., s.38.

${ }^{5}$ L. Trzeciakowski, Przedmowa, w: Samomodernizacja społeczeństw w XIX wieku. Irlandczycy, Czesi, Polacy, red. L. Trzeciakowski, K. Makowski, Poznań 1999, s. 10.

${ }^{6}$ Idem, Wielkopolski program samomodernizacji - ksztattowanie się nowoczesnego społeczeństwa, w: Samomodernizacja społeczeństw, s. 65. 
chorobotwórcze ${ }^{7}$. Leopold Lafontaine zwracał uwagę w 1801 r. na przeciwników postępu, którzy są wrogo nastawieni do nowinek w rodzaju szczepień przeciwko ospie. Wielką zmianą było już wtedy odrzucenie przez lekarzy medycyny religijnej i wiary w cudowne uzdrowienia, podobnie poglądu, że kobietę badać i leczyć należy tak jak mężczyznę, bez zważania na różnicę płci. Jak pisał Lafontaine, „,im zdarzenia bardziej się od naturalnych praw natury oddalają, a przybliżają do cudów, tym mniej godne są wiary, choćby najosobliwsze i przez najwięcej świadectw były potwierdzone"

Jak stwierdza Ragnhild Münch, opieka medyczna państwa z jednej strony należała do środków dyscyplinujących poddanych państwa absolutnego, z drugiej zaś - do narzędzi budowania "państwa dobrobytu”. Prusacy mieli się stosować do zarządzeń medycznych jako posłuszni poddani, nie jako wolni obywatele. Christian Barthel powiada za Michelem Foucault, że w okresie klasycyzmu ciało i zdrowie ulegało odprywatyzowaniu i stawało się obiektem społecznego nadzoru i przedmiotem władzy. Dla państwa przedmiotem troski i dyscyplinowania stała się „ludność”, którą poczęto postrzegać jako bogactwo, siłę roboczą. Zaczęto interesować się przyrostem naturalnym, płodnością i śmiertelnością, stanem zdrowotnym społeczeństwa i sposobami odżywiania ${ }^{10}$. Zagadnienie zdrowotności i medycyny jest wielce znaczące w strukturze kameralizmu, czyli oświeceniowej i merkantylistycznej nauki o funkcjonowaniu państwa i kraju. Kameralizm w niemieckim wydaniu był też wiedzą o optymalnym wykorzystaniu zasobów kraju przez państwo, a wreszcie o sposobach jego działania służących wzrostowi gospodarczemu i pomnożeniu bogactwa kraju. Realizacją tych celów zajmowała się policja, w tym ,policja medyczna”, jak nazwał ją Johann Peter Frank ${ }^{11}$.

Celem tych wszystkich działań był wzrost zamożności i pomyślności mieszkańców, podporządkowany jednak bezpieczeństwu militarnemu kraju. To osiągało państwo przez podatki, które można było uzyskać w wystarczającej wysokości tylko od zamożnych, zdrowych i zdolnych do pracy poddanych. W epoce licznych epidemii różnych chorób zbierających

${ }^{7}$ R. Jütte, Krankheit und Gesundheit in der Frühen Neuzeit, Stuttgart 2013, s. 26-27.

${ }^{8}$ L. Lafontaine, 0 prawdziwej wartości sztuki lekarskiej, „Dziennik Zdrowia dla Wszystkich Stanów” 1801, 1, s. 10-13; idem, O ospie krowiej, „Dziennik Zdrowia dla Wszystkich Stanów" 1801, 3, s. 281-282.

${ }_{9}$ R. Münch, Gesundheitswesen im 18. und 19. Jahrhundert. Das Berliner Beispiel, Berlin 1995, s. 22.

${ }^{10} \mathrm{Ch}$. Barthel, Medizinische Polizey und medizinische Aufklärung. Aspekte der öffentlichen Gesundheitsdiskurses im 18. Jahrhundert, Frankfurt a.M.-New York 1989, s. 9-10, 18.

${ }^{11}$ R. Jütte, op. cit., s. 19; J.P. Frank, System einer vollständigen medicinischen Polizey, t. $1-9,1779-1827$. 
śmiertelne żniwo i ogromnej śmiertelności dzieci był to wielki i dotkliwy problem ${ }^{12}$. W służbę państwa wciągnięta też została ideologia pietyzmu, który już w początku XVIII stulecia kładł silny nacisk na politykę społeczną, opiekę nad ubogimi i sierotami, higienę i wykształcenie ludu. Pietyzm przesycał doktrynę Kościoła, który w Prusach był częścią aparatu państwowego. Pastorzy poza religią stawali się nie tylko urzędnikami, ale i nauczycielami, przekazującymi z ambony także edykty i rozporządzenia dotyczące chorób i leczenia ludzi i zwierząt. Inna rzecz, że przed odczytywaniem dokumentów urzędowych znudzeni wierni wychodzili z kościoła i siła przekazu edyktów była nieco ograniczona ${ }^{13}$.

W obrębie kameralistyki występował natomiast nurt bliski polityce sanitarnej państwa. Był nim populacjonizm. Polityka populacyjna (Peuplierungspolitik) zmierzała do wspierania wzrostu demograficznego i starań o zapewnienie i utrzymanie wysokiej jakości materiału ludzkiego. Głębsza przesłanka stojąca za tą polityką to założenie, że od liczby mieszkańców kraju, którzy wytwarzają dobra materialne, zależy potęga państwa, czerpiącego swą siłę z opodatkowania tychże dóbr. Jak to oceniał w 1808 r. Leopold Krug, wprawdzie lepiej mieć państwo z 5 mln mieszkańców i 300 mln talarów dochodu rocznego niż 10 mln mieszkańców i $500 \mathrm{mln}$ tal., jednak dobrobyt i zamożność idą w parze z rozkwitem demograficznym ${ }^{14}$. Ten sposób widzenia odzwierciedlał zwykle rzeczywistość europejską - kraje gęsto zaludnione to kraje zamożne. Tak też baron vom Stein w urzędowym sprawozdaniu z podróży po Polsce w $1781 \mathrm{r}$. stwierdzał, że słabe zaludnienie kraju jest spowodowane złym położeniem ludności i ogólnie zbyt wielką nierównością. Podobnie uważali następni administratorzy pruscy po $1793 \mathrm{r}^{15}$

Rolę całkowicie zasadniczą odgrywały źródła informacji o stanie demograficznym i sanitarnym kraju, skłaniające do podjęcia określonych działań. Narzędziem dającym informacje w tym zakresie - jak współcześnie mówiono, „okularami państwa” (Staatsbrille) - była statystyka urzędowa (amtliche Statistik). Jej rozmiary, zaangażowane w jej prowadzenie środki są oczywistym dowodem na to, jaką wage przywiązywały władze pruskie do stanu sanitarnego i ogólnie demograficznego kraju. Epidemie

${ }^{12}$ R. Jütte, op. cit., s. 10-11; R. Blaich, Die Epoche des Merkantilismus, Wiesbaden 1973; O. Büsch, Militärsystem und Sozialleben im Alten Preußen, Berlin 1962; E. Heckscher, Der Merkantilismus, t. 1-2, Jena 1932.

${ }^{13}$ C. Hinrichs, Preussentum und Pietismus, Göttingen 1971.

14 „Die Vergrößerung der Menschenmenge ist also sowohl eine Ursach als eine Folge des Vermögens und Reichthums", L. Krug, Abriss der Staatsökonomie oder Staatswirtschaftslehre, Berlin 1808, s. 27-29.

${ }^{15}$ Freiheer vom Stein, Briefe und amtliche Schriften, oprac. E. Botzenhart, W. Hubatsch, t. 1, Stuttgart 1957, s. 127-128. 
stanowiły czynnik centralizujący i mobilizujący dla państwa. Te spektakularne, a przecież nierzadkie klęski wymagały rozwiązań prawnych, służby zdrowia, działań zsynchronizowanych, kordonów sanitarnych na dużych obszarach. Większość zgonów spowodowana była w tym czasie przez choroby epidemiczne, podczas gdy dzisiaj przez choroby krążenia (41\% zgonów w Niemczech w 2010), raka (25\%) i serca. Inna sprawa, że rak uważany był wówczas błędnie za chorobę zakaźnąa ${ }^{16}$.

Oświecenie przynosiło duże zmiany na obszarze instytucjonalizacji i rozwoju publicznej służby zdrowia i podniesienie jej poziomu. Słabła kluczowa wcześniej rola Kościoła. Kościelne szpitale-przytułki (Hospital) przekształcały się w publiczne szpitale lecznicze (Krankenhaus). Inaczej niż dzisiaj ich pacjenci pochodzili przede wszystkim spośród warstw ubogich, których nie było stać na lekarza przychodzącego prywatnie do domu. Zmieniło się to dopiero pod koniec XIX i w XX w. Rozpoczął się rozwój szkolnictwa medycznego, w tym położniczego ${ }^{17}$. Wspomnieć też należy o procesach profesjonalizacji, a więc uzawodowienia i poprzedzania edukacją szkolną zawodów medycznych, czego nie było w medycynie tradycyjnej i ludowej. W ten sposób doszło do degradacji wiejskich akuszerek, położnych, które nie miały przygotowania zawodowego, i narzucenia społeczeństwu sieci medycznej kontroli ${ }^{18}$. Hans Seidel analizuje to zjawisko na przykładzie położnictwa ${ }^{19}$.

Już w połowie wieku XVIII także i w Polsce znakomicie wiedziano, że epidemie stanowią element cyklu kryzysowego, wiodącego od klęski nieurodzaju do niedożywienia czy wręcz głodu ludności na obszarze dotkniętym określonymi problemami. W państwie pruskim zorganizowana była imponująca sieć magazynów zbożowych, które wprawdzie miały i cel militarny, ale w okresie pokoju posiadały zapasy żywności na czas nieurodzaju. Kiedy z powodu niedoborów ceny zboża w okolicy rosły, magazyny utrzymywały ceny stałe, tak że mogła je kupić większa liczba ludzi. Np.w 1795 r., gdy cena zboża poszybowała na dwa i pół talara za korzec (Scheffel), magazyny państwowe sprzedawały je nadal za jednego, wydając 22 tys. wispli (pruska miara zbożowa objętości) zboża ${ }^{20}$. Lekarz Jacek Łopacki pisał o cyklu prowadzącym do epidemii już w 1736 r.: ,kiedy po surowej zimie nastąpiły bardzo dżdżyste wiosna i lato, wraz z powodziami i bardzo wilgotnymi

${ }^{16}$ R. Jütte, op. cit., s. 10-11, 21.

${ }^{17}$ Ibidem, s. 16-17.

${ }^{18}$ M.Foucault, Narodziny kliniki, Warszawa 1999 (oryg. franc. 1963).

${ }^{19}$ H.-Ch. Seidel, Eine neue „Kultur des Gebärens”. Die Medikalisierung von Geburt im 18. und 19. Jahrhundert in Deutschland, Stuttgart 1998, s. 12-18.

${ }^{20}$ A. Skalweit, Die Getreidehandelspolitik und Kriegsmagasinen Verwaltung Preußens 1756-1806, Berlin 1931, s. 186-189. 
wiatrami i trwało to aż do września. Bardzo się zmniejszyła obfitość zbóż, a to które mogło być zebrane było niezbyt dojrzałe i zarażone rdzą. To była największa przyczyna wiejskiej zarazy"21 . Występuje więc ścisły związek między wyżywieniem, głodem, zachorowaniami, ale i nie tylko doraźną, lecz również ogólną kondycją biologiczną i społeczną chłopa ${ }^{22}$. Oczywiście sytuacja chłopów była zróżnicowana,jednak nie tylko zagrodnicy i komornicy, ale i pańszczyźniani gospodarze z włóką ziemi (Bauern, Ganzebauern i Halbbauern) posiadali majątki niewystarczające na dostatnie życie, a nadto obciążone wysokimi świadczeniami.

Stąd gospodarcza polityka państwa miała również na względzie podniesienie poziomu średniej konsumpcji. Starano się to osiągnąć z jednej strony przez protekcjonizm, posunięty do zakazu eksportu płodów rolnych w okresie nieurodzaju, z drugiej przez rozwinięte na ogromną skalę magazynowanie zboża, które było tym chętniej prowadzone, że jego głównym celem były jednak potencjalne zapasy dla wojska. Na koniec wreszcie państwo prowadziło niezwykle aktywną politykę na polu modernizacji gospodarki. Na miejscu pierwszym znajdowało się upowszechnianie ziemniaka, w którym upatrywano szansę na całkowite wyeliminowanie klęski głodu ${ }^{23}$. Współczesne podręczniki medyczne, wspominając o klęsce głodu, odwoływały się jako do środka zaradczego właśnie do ziemniaków ${ }^{24}$. W istocie w okresie 1800-1810 r. nastąpiło znaczne upowszechnienie ich uprawy przede wszystkim w gospodarstwach chłopskich, co wynikało z postrzegania ziemniaków jako pożywienia ubogich ${ }^{25}$. Dalej jednak dodać do tego należy również uprawy koniczyny i roślin pastewnych, mające wpłynąć na rozwój hodowli bydła, a w konsekwencji spowodować przyrost konsumpcji mięsa, mleka i jego przetworów. Rzecz jasna, bez oświecenia, bez postępu wiedzy, mody i prądów umysłowych cała ta działalność byłaby niemożliwa.

${ }^{21}$ Cyt. wg: S. Konopka, Medycyna w Polsce w połowie XVIII wieku w świetle listu Jacka Augustyna Łopackiego, „Archiwum Historii Medycyny” (dalej: AHM) 20, 1957, 1/2, s. 162.

${ }^{22}$ D. Łukasiewicz, Uwagi o położeniu chłopów pod zaborem pruskim (Prusy Południowe i Zachodnie) w końcu XVIII i na początku XIX w., PH 103, 2012, 2, s. 303-331.

${ }^{23}$ E. Klein, Geschichte der deutschen Landwirtschaft, Wiesbaden 1973, s. 13-15; H. Klinckmüller, Die Amtliche Statistik Preussens, Freiburg 1880, s. 42-43; O. Behre, Geschichte der Statistik in Brandenburg-Preussens, Berlin 1905, s. 236-239; K. Zimmermann, Fryderyk Wielki i jego kolonizacja rolna, Poznań t. 2, 1915, s. 349-350; Vorschläge zur Verbesserung der Bauern in Südpreussen, oprac. A. Koerth, „Deutsche Wissenschaftliche Zeitschrift im Wartheland" 1940, z. 2, s. 277.

${ }^{24}$ F.A. May, Entwurf einer Gesetzgebung über die wichtigsten Gegenstände der medizinischen Polizei, Mannheim 1809, s. 21.

${ }^{25}$ A.C. Holsche, Geographie und Statistik von West-Süd-und Neu-Ostpreussen. Nebst einer kurzen Geschichte des Königreichs Polen zu dessen Zertheilung, t. 2, Berlin 1804, s. 422; H. Grossmann, Struktura społeczna i gospodarcza Księstwa Warszawskiego, „Kwartalnik Statystyczny" 2,1925, 1, s. 75. 


\section{Ocena sytuacji zdrowotnej na ziemiach polskich przez władze pruskie}

W takim kontekście odbywała się po rozbiorach analiza sytuacji sanitarnej na ziemiach polskich przez władze pruskie. Ocena ta wypadła bardzo niepomyślnie, co nie odbiegało specjalnie od refleksji z czasów saskich i stanisławowskich, a więc nie wynikało tylko z ksenofobii i stereotypów ${ }^{26}$.Zakwestionowano poziom lecznictwa, które w zbyt dużym stopniu zależało od osób nie posiadających odpowiednich kwalifikacji, ale i stan wiedzy medycznej pacjentów ze wszystkich warstw społecznych. Już długo wcześniej lekarz J. Łopacki w 1744 r. relacjonował sytuację następująco: „Ponieważ tutaj słabo się rozwijały studia lekarskie, nie bez przykrości spostrzegamy, że za lekarza podaje się byle prostak, laik, Żyd, mnich, kuglarz, balwierz i stara baba. Dzięki temu tylko niewielu ludzi uprawia tę sztukę metodycznie i rozumowo" 27 . Kiedy dziadek Joachima Lelewela, lekarz Henryk Loelhoeffel, przybył w 1736 r. z Niemiec i próbował założyć w Warszawie szkołę chirurgiczną, musiał zrezygnować z powodu wrogości tłumu, przeciwnego sekcjom zwłok ${ }^{28}$. Musimy pamiętać, że w średniowieczu żywy był lęk przed zmarłymi, sekcje zwłok przeprowadzano o zmierzchu lub o świcie. Już jednak we Francji epoki oświecenia pojawił się przełom. Sekcje zwłok stały się manifestacją racjonalności i nowego ducha. Zwłoki na zajęciach $\mathrm{z}$ anatomii masowo kroili studenci ${ }^{29}$. Tak więc poziom świadomości medycznej na ziemiach polskich był znacznie niższy niż na Zachodzie. Dawne oceny Władysława Smoleńskiego wydają się do dzisiaj aktualne ${ }^{30}$.

Z pewnością słusznie stwierdza Michał Hanecki, a później Tadeusz Srogosz już dla czasów stanisławowskich, że przytłaczająca większość pacjentów korzystała z usług znachorów, babek, szarlatanów, chirurgów i felczerów, a tylko zamożni z pomocy lekarzy z wykształceniem uniwersyteckim ${ }^{31}$. Podobnie Friedrich Herzberg stwierdzał w 1798 r., że lekarze są tylko w kilku większych miastach, a w małych wyłącznie chirurdzy i balwierze, zwykle Żydzi bez kwalifikacji, których operacje chirurgiczne przypominają pracę kata i rzeźnika. Wspomina dziewczynę,

${ }^{26}$ Analizuję ją w pracach: D. Łukasiewicz, Czarna legenda Polski. Obraz Polski i Polaków w Prusach 1772-1815, Poznań 1995, s. 56-74; idem, Warkocz znad Wisły. Pruski stereotyp brudnej Polski czy prawda historyczna?, ,Medycyna Nowożytna” 2, 1996, 2, s. 83-104.

${ }^{27}$ S. Konopka, op. cit., s. 160.

${ }^{28}$ T. Srogosz, Problemy sanitarno-zdrowotne $w$ działalności administracyjnej Rzeczypospolitej w okresie stanisławowskim, Łódź 1993, s. 50-51.

${ }^{29}$ M. Foucault, op. cit., s. 161-163.

${ }^{30}$ W. Smoleński, Przewrót umysłowy w Polsce wieku XVIII, Warszawa 1949, s. 266-297.

${ }^{31}$ T. Srogosz, op. cit., s. 48-49; M. Hanecki, Środowisko medyczne w czasach stanisławowskich, AHM 36, 1973, 4, s. 272. 
której chirurg z powodu jednego małego wrzodu obciął całą górną wargę. Balwierze wiedzieli, że pacjent uznaje za godne zaufania zabiegi puszczania krwi i przeczyszczenia, i stosowali te kuracje, które były modne i oczekiwane $^{32}$. Minister Prus Południowych Karl Otto Voß pisał o „głębokim moralnym i fizycznym upadku" niższych klas ludności, kontrastującym jaskrawo z położeniem szczęśliwszych poddanych króla w starszych prowincjach Prus. Takich opinii było bez liku i nie ma potrzeby ich mnożyćs3.

Przepaść między wschodem a zachodem była tu jednak mniejsza, niż się zdaje. Robert Jütte ocenia, że ok. 90\% społeczeństwa przednowoczesnego leczyło się w domu i nie korzystało z pomocy lekarskiej. Podobnie o Francji pisze Georges Vigarello ${ }^{34}$. Warstwy niższe sięgały zwykle po pomoc znachorów, babek, chirurgów i balwierzy oraz lekarza szpitalnego w szpitalu dla biednych.Jütte wskazuje wszakże, że warstwy niższe jednak z pomocy lekarskiej w pewnym niewielkim zakresie korzystały. Badania 2314 protokołów z wizyt lekarskich w XVII w. z Kolonii wskazują mniej więcej na równy podział między warstwę niższą i średnią oraz wyższą ${ }^{35}$.

Po 1793 r. Prusacy zaczęli zbierać bardzo jeszcze niedoskonałe informacje statystyczne na temat zdrowotności, przyczyn zgonów i chorób, dzięki czemu zyskali lepsze rozeznanie sytuacji niż władze polskie przed rozbiorami. Tabela „Specyfikacja Generalna chorób i przypadków, na które ludzie w ciągu roku umierali" ${ }^{\prime 36}$ oczywiście nie odnotowuje chorób rzeczywistych, ale ówczesne błędne kwalifikacje i rozpoznania,np.na podstawie takich objawów zewnętrznych, jak ,fryzle i petocie”. Mimo to jednak z owych niedoskonałych zestawień widać jasno, że ogromnym problemem były choroby epidemiczne, przede wszystkim, jak wszędzie w Europie, ospa. Szacuje się, że pod koniec XVIII w. umierało na nią rocznie na kontynencie 400 tys. osób i śmiertelność - jeżeli nie było szczepień - wynosiła 20-40\% zachorowań. Przy zaszczepieniu ospy ludzkiej ryzyko śmierci spadało do 1:182 zachorowania (tj. poniżej 1\%) ${ }^{37}$. Był to zresztą okres euforii po wynalezieniu szczepień ospą krowią. W Berlinie lekarz Johann Immanuel Bremer założył specjalną szkołę szczepień „Vaccinations-Schule”, a w 1802 r. został kierownikiem królewsko-pruskiego instytutu szczepień, który prowadził szczepienia masowe i bezpłatne ${ }^{38}$.

${ }^{32}$ F. Herzberg, Süd-Preußen und Neu-Ostpreußen, Berlin 1798, s. 159-160.

${ }^{33}$ Das Jahr 1793. Urkunden und Aktenstücke zur Geschichte der Organisation Südpreußen, red. R. Prümers, Posen 1895, s. 262-263.

${ }_{34}$ G. Vigarello, Historia zdrowia i choroby. Od średniowiecza do wspótczesności, Warszawa 1997 (oryg. franc. 1993).

${ }^{35}$ R. Jütte, op. cit., s. $16-17,120$.

${ }^{36}$ AGAD, Biblioteka Ordynacji Zamoyskich 96, b.p.

${ }^{37}$ R. Jütte, op. cit., s. 53-54.

${ }^{38}$ Ibidem, s. 55. 
W departamencie poznańskim w 1800 r. spośród 25442 zmarłych 7638 osób zmarło z powodu ospy, 649 z powodu odry ${ }^{39}$. W 1806 r. odnotowano blisko 4 tys. zgonów z powodu ospy. Podobnie obfite żniwo zbierała gruźlica, czyli suchoty (ok. 1300 ofiar), febra, odra, dezynteria i in. ${ }^{40} \mathrm{~W}$ departamencie poznańskim wykaz zgonów wg rodzajów chorób z $1797 \mathrm{r}^{41}$ zawiera 53 przyczyny zgonów. Na 15,4 tys. zgonów ogółem, na ospę zmarło 1191 osób, na odrę 1125, febrę 666, Podano aż 1863 przypadki zgonu z powodu „zębów”, tylko 91 na choroby weneryczne, a 10 na raka. Było 229 przypadków śmierci okołoporodowej. Na 15,5 tys. zgonów 5,4 tys. stanowiły dzieci do pierwszego roku życia, 3 tys. - dzieci 1-5 roku życia i 0,55 tys. - 5-10 roku życia. Nie oznacza to jednak, jak czasem się zdaje, że potem śmiertelność gwałtownie malała. Była ona stosunkowo wysoka również po 10 oku życia i przez cały okres jego trwania. Jak wiadomo, śmiertelność dzieci wynikała nie tylko z chorób epidemicznych (ospa, odra), ale często z chorób przewodu pokarmowego, z niewłaściwych sposobów żywienia i niekarmienia piersią oraz niewłaściwej opieki ${ }^{42}$. W środowiskach wykształconych zdawano sobie sprawę z wagi karmienia piersią. Jak czytamy w tekście południowopruskim z 1805 r., matka, która oddaje dziecko do mamki, jest narażona na niebezpieczeństwo:

mleko, którego odmawia swemu dziecku, zamienia się w zgubną truciznę, która staje się dla nie[j] źródłem niewyczerpanych chorób i męczarni [--]. Matki takowe, jeżeli tylko nazwiska tego są godne, zwyczajnie drogo przypłacają srogości tej [- - ] mleko bowiem nie mając przyrodzonego odbytu, rozlewa się po wszystkich członkach i sprawia najokropniejsze spustoszenia. Stąd niektóre dostały pomieszania zmysłów, inne utraciły wzrok albo słuch, dlatego, że się utworzyły pokłady mleczne w jakiej części wewnętrznej mózgu ${ }^{43}$.

To zastraszanie było w jakimś sensie zasadne, a także ostrzeganie, że brak laktacji powoduje natychmiastową płodność i zachodzenie w ciążę: „brzemienności ich zbyt prędko jedne po drugich następują"44.

Zalecano także matkom dbałość o siebie podczas ciąży, co miało mieć wpływ na kondycję fizyczną ich dzieci. Wskazywano więc na konieczność częstego przebywania na świeżym powietrzu, spania dłużej niż zwykle,

\footnotetext{
${ }^{39}$ AGAD, Generalne Dyrektorium Prusy Południowe (dalej: GDPP), I, 1732, k. 205-210.

${ }^{40}$ AGAD, Biblioteka Ordynacji Zamoyskich 96, b.p.

${ }^{41}$ AGAD, GDPP, I, 1745.

42 O pokarmach i napojach chimicznie rozebranych, „Nowy Pamiętnik Warszawski”

${ }^{43}$ Ibidem, s. 315 .

${ }^{44}$ Ibidem, s. 317.
} 1805,60 , s. 316. 
unikania mięs solonych, potraw korzennych, ciast, picia dużej ilości wina, a także unikania jazdy konnej, tańca, jazdy powozami, ciężkiej pracy fizycznej, pożycia małżeńskiego - „założyć granice powinności małżeńskiej" 45 .

W zestawieniu śmiertelności dla jednego z trzech departamentów Prus Południowych, departamentu poznańskiego, w $1800 \mathrm{r} .{ }^{46}$ martwe urodzenia stanowiły tu 1,3\% urodzeń, 28,3\% zgony do pierwszego roku życia dziecka, 23,7\% zgony dzieci w wieku 2-5 lat i 6,7\% dzieci w wieku 6-10 lat, a więc $58 \%$ dzieci do 10 roku życia. Statystyka departamentu kaliskiego ${ }^{47}$ wskazuje, że dzieci martwo urodzone stanowiły w roku 1803 1,5\% zgonów, dzieci zmarłe do 1 roku życia 34,9\% zgonów, dzieci zmarłe 1-5 roku życia 19,3\% zgonów, zmarłe od 6-10 roku życia 3,6\% zgonów. Ogółem dzieci zmarłe do 10 roku życia stanowiły 59,2\% wszystkich zgonów, osoby zmarłe od 10 do 50 roku życia kolejne $20,3 \%$, tak że zgony po pięćdziesiątce stanowiły zaledwie 20,5\% wszystkich zmarłych. Stanowiący kolejną pozycję spis zgonów wg chorób obejmował ogółem 53 przyczyny zgonów. W analizowanym spisie kaliskim 7,7\% zgonów spowodowała ospa, 7,3\% odra, 4,4\% febra zgniła, $11 \%$ choroby „zębów”. W departamencie poznańskim na 22378 zgonów 328 przypadało na śmierć okołoporodową kobiet ${ }^{48}$. Przy okazji możemy skonstatować, że w porównaniu z innymi pruskimi prowincjami struktura zgonów na ziemiach polskich nie różniła się niczym szczególnym, inaczej mówiąc, skuteczność policji sanitarnej była w stosunku do zamierzeń niewielka $^{49}$. Cezary Kuklo sądzi, że w rzeczywistości statystyka śmierci okołoporodowej i niemowląt była bardzo niekompletna ${ }^{50}$.

Warto pamiętać, że przechowywano $\mathrm{w}$ domach niezliczoną ilość mniej lub bardziej skutecznych leczniczych środków roślinnych i specyfików, a w szlacheckim dworze oddalonym bardziej od miasta istniało wręcz pomieszczenie zwane apteczką albo „chowalnią”, w której m.in. znajdowała się szafa na lekarstwa. Przy niskiej skuteczności medycyny oficjalnej domowe sposoby odgrywały dużo większą niż dzisiaj rolę. Po apteczkę domową sięgano przed przybyciem lekarza. Domowym specja-

${ }^{45}$ Ibidem, s. 314-315.

${ }^{46}$ AGAD, GDPP, I, 1732, k. 205-210.

${ }^{47}$ AGAD, GDPP, III, Nr 13a, b.p.; statystyka zestawiająca lekarzy, chirurgów, położne, balwierzy, w: Opisy miast polskich z lat 1793-1794, oprac. J. Wąsicki, t. 1-2, Poznań 1960-1962.

${ }^{48} \mathrm{~J}$. Landsberger, Aus der Medicinalverwaltung Posens am Ende des vorigen Jahrhunderts, „Zeitschrift der Historischen Gesellschaft für die Provinz Posen” (dalej: ZHGPP), 8, 1893, s. 323.

49 „Die Sterblichkeit nach Todesursachen während des Jahres 1777”, w: O. Behre, op. cit., s. 150; H. Schulz, Berlin 1650-1800. Sozialgeschichte einer Residenz, Berlin 1987, tab. 19.

${ }^{50}$ C. Kuklo, Demografia Rzeczypospolitej przedrozbiorowej, Warszawa 2009, s. 402-405. 
listą od leków miała być kobieta, co Karolina Nakwaska wiązała z jej macierzyńską, opiekuńczą naturą ${ }^{51}$.

Problematyka zdrowotna jest złożona i zróżnicowana i wskazuję tu tylko na jej elementy zasadnicze. Warto jednak zaznaczyć, że ważne były też sprawy stomatologiczne. Zasadniczo codzienna opieka w tym zakresie nie istniała, stomatologii jeszcze nie było i działali „wyrwizęby", których interwencja kończyła się na ekstrakcji, przy braku środków anestezjologicznych. Na zęby jednak z estetycznego punktu widzenia uwagę zwracano, chociaż wzmianki na ten temat są rzadkie. Antoni Magier wspomina, że król Stanisław August „troskliwym był zawsze w utrzymaniu ochędostwa zębów i za pierwszą uznawał zaletę przyjemności kobiety w zachowaniu ich białości; dlatego kobietki wesołe śmiejąc się lub mówiąc śmiało swe usta otwierały, nie tak jak dawniejsze, które stulając swe usteczka, rączką albo wachlarzem brzydkie swe zęby zwykle zasłaniać musiały" ${ }^{2}$.

Z drugiej strony nie należy sądzić, że w Prusach i Niemczech sytuacja była zasadniczo odmienna. Wybitny lekarz Christoph Wilhelm Hufeland ubolewał w początku XIX w.: „Co to pomoże, że 1/6 narodu, która żyje w miastach, znajduje się pod opieką najlepszych zakładów medycznych i lekarzy, podczas gdy pięć szóstych, które żyją na wsi, są tej opieki pozbawione" 53 . W 1750 r. na 51 lekarzy w Brandenburgii 37 pracowało w Berlinie. Honoraria lekarzy za wizytę ustalone zostały przez taksy w $1725 \mathrm{r}$. i pozostały niezmienione do roku 1802 . Wizyta lekarska kosztowała jednego talara, to znaczy pół tygodniówki robotnika manufaktury albo czeladnika. Owszem, lekarzy było zdecydowanie więcej i istniały struktury publicznej służby zdrowia na początkowym etapie jej rozwoju, ale na wsiach podobnie jak w Polsce powszechni byli znachorzy, baby, a chirurdzy również byli rzemieślnikami. Przesądów było bardzo wiele i powszechne pruskie prawo krajowe penalizowało je jako przestępstwo, z czego wycofano się dopiero w Kodeksie karnym z $1851 \mathrm{r}$. Podobnie w handlu dostępne były tylko medykamenty zatwierdzone urzędowo, ze względu na zaśmiecanie rynku produktami uzdrawiaczy i szarlatanów. Wróżbiarstwo karano więzieniem. Przesądy skutkowały jeszcze długo później sprawami karnymi, jak np. w przypadku pobicia chłopa na cmentarzu, którego dwaj mężczyźni wzięli za upiora. Nie było wiadomo, czy ich karać, skoro bili w dobrej intencji. Barbara Duden wskazuje, że również

${ }^{51}$ Karolina z Potockich Nakwaska, Dwór wiejski, Poznań 1843, s. 16-19; T. Srogosz, op. cit., s. 50-51.

${ }^{52}$ A. Magier, Estetyka miasta stołecznego Warszawy, Wrocław 1963, s. 65-66.

${ }^{53}$ T. Srogosz, op. cit., s. 269. 
środowisko niemieckich lekarzy z wykształceniem uniwersyteckim nie było wolne od problemów. W grę wchodziło kupowanie dyplomów, pisanie dysertacji przez profesorów, bardzo różny poziom studiów ${ }^{54}$.

W Prusach Południowych L. Lafontaine zachęcał księży, „lekarzy duszy” - jak pisał, aby czytali jego „Dziennik Zdrowia” i pomagali ubogim włościanom także w sprawach zdrowotnych:

Wy to najpierwsi po wsiach jesteście, w których biedni w swoich potrzebach szukają pomocy. Wasze lepsze wychowanie, wasz stan na wsparcie i pociechę cierpiących poświęcony, ułatwią wam nabycie tej umiejętności, dobro bliźnich waszych w celu mający. Wieśniak, który czytać nie umie i zawsze koło roli zatrudniony jest całodzienną pracą, na całą waszą zasługuje uwagę. Nie zapominajcie nigdy, że jesteście pasterzami powierzonej wam trzody, że ta klasa na wyżywienie nas wszystkich krwawym zalewa się potem i ze wszystkich względów godna jest waszego starania i pieczołowitości ${ }^{55}$.

Przedmiotem ostrej krytyki był stan higieniczny i sanitarny miast, wiosek, dróg i mieszkańców. Jak wiadomo, w epoce stanisławowskiej podjęto starania o poprawę tej sytuacji, rozwinęła się działalność policji, pracowano nad poprawą bruków i uprzątaniem nieczystości. W Warszawie działała Komisja Brukowa, ustalając w 1743 r. zasadę, że właściciele domów nie mają prawa wyrzucać śmieci i błota na ulicę, a błoto i śnieg z ulicy sami muszą gromadzić w kupy, by miasto mogło je wywieźć. Marszałek Michał Jerzy Mniszech w 1784 r. nakazywał, że „pomyj, mydlin, fusów, lagrów i innych rzeczy błoto pomnażających i fetor czyniących" nie wolno gdzie indziej wylewać, jak tylko do rynsztoków, tudzież, że właściciele domów obowiązani byli podczas deszczów ulewnych wysłać swoich ludzi, aby „rozrządzając błoto, oneż rynsztokami do kanałów przegarniali ${ }^{56}$. Odpadki i śmieci gromadzono pod Warszawą w jednym miejscu, które otrzymało nazwę Góry Gnojowej. Kilkadziesiąt lat deliberowano nad jej usunięciem, w końcu Stanisław August nakazał obłożyć ją darnią i nazwał Górą Zieloną. Jednak nadal przez cały okres południowopruski wydzielał się z niej fetor, śmieci wywożono tam jak dotąd i problem rozwiązano dopiero $\mathrm{w}$ połowie XIX w. ${ }^{57}$

${ }^{54}$ N. Freytag, Aberglauben im 19. Jahrhundert. Preußen und seine Rheiprovinz zwischen Tradition und Moderne (1815-1918), Berlin 2003, s. 37-38, 51, 397-398; B. Duden, Historia ciała. Lekarz i jego pacjentki w osiemnastowiecznym Eisenach, Warszawa 2014 (oryg. niem. 1987), s. 88-92.

${ }^{55}$ L. Lafontaine, Przedmowa, „Dziennik Zdrowia dla Wszystkich Stanów” 1801,1, b.p.

${ }^{56}$ F. Giedroyć, Warunki higieniczne Warszawy w wieku XVIII, Warszawa 1912, s. 24-27.

${ }^{57}$ Ibidem, s. 36-37. 
Generalnie sytuacja nie ulegała jednak zmianie, również w wielkich miastach poprawa była połowiczna. Już w epoce oświecenia mówiono o zrujnowaniu miast przez wojny XVII i XVIII w. Zauważono całkowity niedowład policji sanitarnej. W skrajnych wypadkach, jak w Rynarzewie w 1772 r., magistrat na zapytanie o stosunki sanitarne odpowiedział władzom, że nie wie, co to jest policja sanitarna ${ }^{58}$. Miasta były zrujnowane, chaty chłopskie w fatalnym stanie, zamieszkiwane razem ze zwierzętami, ulice były słabo oczyszczane, źle albo wcale nie brukowane, kloaki nie opróżniane. Do tego dochodziły cuchnące jatki z mięsem i śledziami, zaniedbane studnie miejskie, brak kontroli jakości chleba, mięsa, alkoholu, szwendające się po ulicach stada psów, brud, którego przejawem był bardzo powszechny kołtun włosów (Weichselzopf) połączony z robactwem, brudem, ciągłym drapaniem się. Takie oceny w początku XIX w. były dosyć powszechne ${ }^{59}$.

O Prusach Nowowschodnich i Południowych August Holsche pisał, że miasta są tam „zaniedbane” i w „żałosnym stanie”, domy w przytłaczającej większości drewniane, kryte słomą i gontem, ulice zwykle nie wybrukowane i powszechnie brudne ${ }^{60}$. Polacy pisali to samo. Fryderyk Skarbek:

Nie mogłem bowiem zrazu przystać na to, aby dać to nazwisko żydowskim osadom, złożonym z kilkudziesięciu drewnianych domów, na błotnistej powierzchni wzniesionych, w których nieliczni chrześcijanie byli rolnikami, nie różniącymi się niczym od chłopów, a wszyscy Żydzi handlowaniem, oszukiwaniem szlachty i rozpajaniem włościan zajęci, a których cały przemysł rękodzielny kończył się na szyciu butów i sukman dla żywych i na robieniu trumien dla umarłych ${ }^{61}$.

Franciszek Gajewski:

Miasteczka były nieomal wszystkie bez bruku. Składały się z domków drewnianych, gontami lub słomą krytych; rynek, zwykle błotnisty,

${ }^{58}$ M. Beheim-Schwarzbach, Der Netzedistrikt in seinem Bestande zur Zeit der ersten Theilung Polens, ZHGPP 7, 1892, s. 221.

${ }^{59}$ D. Łukasiewicz, Warkocz znad Wisły, s. 83-104; idem, Czarna legenda Polski, s. 56-74 (tu dalsze źródła i literatura); T. Srogosz, Trwałość i zmienność warunków zdrowotnych ludności chłopskiej w Rzeczypospolitej w XVIII wieku, „Medycyna Nowożytna” 4, 1997,1/2, s. 89.

${ }^{60}$ A.C. Holsche, op. cit., t. 1, s. 138; t. 2, s. 269; B. Baranowski, Życie codzienne małego miasteczka w XVII i XVIII wieku, Warszawa 1975, s. 17; C. Mayer, Studien zur Verwaltungsgeschichte der 1793 und 1795 von Preussen erworbenen polnischen Provinzen, Berlin 1902, s. 10; W. Rusiński, Życie codzienne w Kaliszu w dobie Oświecenia, Poznań 1988, s. 17, 19, 22, 26-27, 29.

${ }^{61}$ F. Skarbek, Pamiętniki Seglasa, Warszawa 1898, s. 56-57. 
ozdobiony był pośrodku ratuszem, w którym mieściła się karczma. Domostwa naokoło rynku takiego opatrzone były zwykle podcieniami; rzadko kiedy spostrzegano kamienicę murowaną, dachówką krytą, w miastecz$\mathrm{ku}$, a jeżeli się w nim znajdowała, należała niezawodnie do Niemca, przybyłego z Prusakami. Lubo bruku nigdzie nie było, kazano nam wszędzie płacić brukowe. Chociaż z niebezpieczeństwem życia przeprawiano się po mostach, pobierano wszędzie mostowe. Najwęższa grobelka miała ustanowionego poborcę, żądającego myta drogowego. Podatek taki szedł na korzyść dziedzica, do którego należało miasto, most czy grobla. Arendował go zawsze Żyd, który, jak mógł, obdzierał przejeżdżających ${ }^{62}$.

Dla naprawy sytuacji w miastach już przed rozbiorami władze powoływały Komisje Boni Ordinis, które pisały dramatyczne raporty o złym stanie cywilizacyjnym miast. „Przez pole furą od biedy można było jechać, a ulicami niektórych miast tylko pieszo lub konno dostawano się do rynku. Broniły wstępu do niego trzęsawiska i stosy gruzów i śmiecia. Uprzątnięcie więc tego rumowiska z ulic i rynków było najpilniejszym zadaniem, a następnie sporządzenie, względnie przywrócenie dawnych jakich takich bruków, jakiej takiej kanalizacji, by nieczystości z miasta spłynąć mogły. O przywróceniu natomiast zasypanych i od przeszło stu lat nieczynnych wodociągów nawet mowy być nie mogło i nie było"63.

Halina Szeflińska mówi o „opłakanym stanie sanitarnym” Sieradza w końcu XVIII w. Zdewastowane liczne budynki stawały się siedliskiem szczurów. Domy były prawie wyłącznie drewniane, często wymagające remontu i grożące zawaleniem. Znacznie gorsza niż w mieście sytuacja panowała na przedmieściach. Ulice były zaniedbane, pełne błota wiosną i jesienią, nie odśnieżone i oblodzone zimą, wraz z podwórkami służyły za śmietniki i ścieki. Z nie najlepszej jakości słynęła woda z płytkich studzien $^{64}$.

Podobnie sytuacja sanitarna Poznania krytykowana była przez całe XVIII stulecie. Już w opisie polskim z 1756 r. czytamy o popękanym ze wszystkich stron ratuszu, wymagającym naprawy bruku na rynku, kanałach zatkanych przez nieczystości i gruz, złych brukach, zrujnowanych

${ }^{62}$ F. Gajewski, Pamiętniki, t. 1, Poznań 1913, s. 11-12.

${ }^{63}$ J. Ptaśnik, Miasta i mieszczaństwo w dawnej Polsce, Warszawa 1949, s. 323-326; por. też T. Korzon, Wewnętrzne dzieje Polski za Stanisława Augusta (1764-1794), t. 2, KrakówWarszawa 1897, s. 303-305, 322; H. Samsonowicz, M. Bogucka, Dzieje miast i mieszczaństwa w Polsce przedrozbiorowej, Wrocław 1986, s. 368-370, 440, 576-577; J. Wojtowicz, Miasta epoki Oświecenia, w: Polska w epoce Oświecenia, red. B. Leśnodorski, Warszawa 1971, s. 216-217.

${ }^{64}$ H. Szeflińska, Warunki zdrowotne Sieradza w końcu XVIII w., AHM 40, 1977, 2, s. 201-203. 
domach i bramach. Sytuacja poprawiła się po 1779 r. na skutek działania Komisji Dobrego Porządku, jednak jak wspominał spacerowicz, w 1793 r. zapadał się nawet w okolicach rynku po łydki w błocie i kale. Także na rynku były kupy i hałdy nieuprzątniętych śmieci. Do sprzątania ulic zobowiązani byli chłopi z poznańskich wsi Górczyn, Jeżyce, Winiary, Wilda, Dębiec i Luboń, i w końcu zaczęto to egzekwować. Nieczystości wywożono we wtorki, czwartki i niedziele wozami, których zbierało się nawet 20. Czystość zaniedbywali też jednak właściciele domów, powszechną praktyką było, szczególnie w nocy, wylewanie nieczystości, np. zawartości nocników, na ulicę. Zanieczyszczanie miasta zaczęto karać mandatami w wysokości 5 reichstalarów (rtl.). Do czyszczenia rynsztoków wyznaczony został przez władze „rynsztokowy” z gażą 5 florenów polskich tygodniowo. Z czasem zaczęto też brukować ulice. Jednak w 1802 r. nadal narzekano, że ulica na przedmieściu św. Marcin prowadząca z miasta na Berlin jest w tak złym stanie, że wiosną i jesienią trudno nią przejechać i podróż grozi wywróceniem pojazdu, a koła zapadają się po osie w błocie. Jak zauważył Rodgero Prümers, miasto otoczone było zrujnowanymi średniowiecznymi murami, co robiło fatalne wrażenie. Centralny punkt Poznania tworzył rynek, od którego już wtedy odchodziły ulice Wrocławska, Wrońska, Szeroka, Wodna i 14 zaułków, wszystko wybrukowane, ale słabo i źle, domy pobudowane zbyt ciasno, bez dostępu światła i powietrza, jak to w urokliwym i malowniczym, ale niezdrowym średniowiecznym stylu zabudowy. Jednak na tle innych miasto czyniło pozytywne wrażenie i uważano je za najbogatsze w Wielkopolsce. A. Holsche, podobnie jak wielu innych obserwatorów, pisał, że Poznań jest miastem znacznym, $\mathrm{z}$ rozwiniętymi miejskimi zawodami, a w obrębie murów wszystkie kamienice są murowane, co, jak stwierdzał, w Polsce należy do rzadkości. I tutaj jednak najzamożniejsza część ludności była głównie pochodzenia niemieckiego ${ }^{65}$.

Radykalnie lepiej wyglądała sytuacja Gdańska czy Berlina. W tym ostatnim wypadku Ludwig Formey zwracał uwagę, że domy są murowane trzy-, cztero-, a nawet pięciopiętrowe, zbudowane regularnie, obszerne, nie stłoczone niezdrowo i ciasno. Ulice szerokie, proste, a więc „zdrowe” dla mieszkańców. Domy posiadają rynny, które odprowadzają nieczystości i wodę z domów. Ulice i chodniki czyszczone były na koszt publiczny,

${ }^{65}$ R. Prümers, Die Stadt Posen in südpreussischer Zeit. I. Das Stadtbild, ZHGPP 22, 1907, s. 163-164, 167-175; R. Breyer, Die Stadt Posen in südpreußischer und herzoglich Warschauer Zeit (1793-1815), w: Geschichte der Stadt Posen, red. G. Rhode, Neuendettelsau 1953, s. 81; D. Łukasiewicz, Czarna legenda Polski, s. 92; M. Jaffe, Poznań pod panowaniem pruskim, Poznań 2012, s. 78; J. Wojtowicz, Miasto europejskie w epoce Oświecenia i Rewolucji Francuskiej, Warszawa 1972, s. 157. 
a nieczystości wylewano do Sprewy ${ }^{66}$. Warszawa tymczasem, o której już wspominałem, przedstawiała obraz opłakany ${ }^{67}$.

Problemy z higieną osobistą i kołtun miały poważny zakres. Jędrzej Kitowicz w XVIII w. pisał, że na Mazowszu na trzy głowy dwie „kołtonowate" ${ }^{68}$. Lekarz wielkopolski Teodor Matecki podawał z urzędowej sprawozdawczości, że jeszcze w 1842 r. w Wielkim Księstwie Poznańskim było 5327 przypadków kołtuna ${ }^{69}$. W 1902 r. w całej monarchii pruskiej było 6500 osób z kołtunem, w tym w rejencji poznańskiej 2507, bydgoskiej 1354, kwidzyńskiej 1354, gdańskiej 250 i królewieckiej 153. Więc właściwie wszystkie przypadki rejestrowano we wschodnich prowincjach Prus. Te informacje rzutują na nasze wyobrażenie o epoce przedstatystycznej, gdy problem na pewno nie był mniejszy ${ }^{70}$.

W wypadku kołtuna zmagały się ze sobą teoria higieniczna i chorobowa. Matecki uspokajał, żeby pacjenci nie wpadali w panikę - kołtun można bez strachu o życie obciąć ${ }^{71}$. Lafontaine sądził, że przypadłość jest zaraźliwa, występuje u wszystkich stanów, w każdym wieku i każdej płci oraz w stosunku do każdego koloru włosów, na co sam zwracał uwagę. „Ta choroba jest znajoma od początku Wisły (skąd podobno jej niemieckie imię Weichselzopf pochodzi) aż do gór karpackich, w Litwie, białej i czerwonej Rusi i w Tartarji. Jednak w niektórych stronach jest częstszą. Za panowania króla Augusta III przeszła z Warszawy do Saxonii"72. Fałszywym kołtunem nazywał stan włosów biorący się z braku higieny ${ }^{73}$. Inni sądzili jednak, że brud i brak grzebienia to problem zasadniczy ${ }^{74}$. Wiek XVIII znał też jednak problemy higieniczne i zdrowotne elit spowodowane przez peruki. W Berlinie znany oświeceniowy pisarz Friedrich Nicolai opublikował nawet w 1801 r. rozprawę Über den Gebrauch der falschen Haare und Perucken in alten und neueren Zeiten. Eine historische Untersuchung, gdzie wskazywał przede wszystkim na polityczne znaczenie peruki, odrzuconej przez jakobinów. Zwracał natomiast uwagę, że wcześniej elity i królowie promowali peruki, również i ze względu na wagę perukarstwa w gospodarce narodowej, a Wielki Elektor Fryderyk Wilhelm w 1698 r. miał wprowadzić podatek od peruk, 6\% na krajowe i $25 \%$ na za-

${ }^{66}$ L. Formey, Versuch einer medizinischen Topographie von Berlin, Berlin 1796, s. 8-9.

${ }^{67}$ F. Giedroyć, op. cit., s. 6-7.

${ }^{68}$ J. Kitowicz, Dzieje obyczajów za panowania Augusta III, Warszawa 1985, s. 314.

${ }^{69}$ T. T. Matecki, Rady i nauki starego lekarza, Poznań 1867, s. 136-137.

${ }^{70}$ H. Florkowski, Kołtun, „Przyjaciel Ludu” (Leszno), 1989, 3 (21), s. 12-13.

${ }^{71}$ T. T. Matecki, op. cit., s. 140-141.

${ }^{72}$ L. Lafontaine, O kołtunie, „Dziennik Zdrowia dla Wszystkich Stanów” 1801, 6, s. 338.

${ }^{73}$ Ibidem, s. 346-347.

${ }^{74}$ D. Krysa-Leszczyńska, Poglady polskich lekarzy na istotę choroby zwanej „,kottunem”, AHM 40,1977, 2, s. 213-215; H. Biegeleisen, Lecznictwo ludu polskiego, Warszawa 1929, s. 256. 
graniczne, z którego zwolnione były dzieci poniżej lat 12, pastorzy, nauczyciele i uczniowie. Wielkie barokowe peruki z oszczędności odrzucił już Fryderyk Wilhelm I ${ }^{75}$.

$\mathrm{Na}$ stosunek do higieny osobistej wpływało wiele przesądów. Lafontaine pisał, że od kąpieli w Wiśle stosowanej dla czystości można się pochorować i dostać biegunki oraz innych przypadłości. Wieczorem między 18.00 a 19.00 na czczo zezwalał się kąpać. Zalecał już jednak kąpiele w wannie, w domu. Wśród pisarzy oświeceniowych (Ludwik Perzyna) kładziono duży nacisk na kąpiele i mycie. Praktycznie jednak mydło było cały czas rzadkością, zwłaszcza wśród chłopów, i stosowano raczej ług. Lafontaine zwracał też uwagę na fatalny czasem wpływ mody na zdrowie - dawne, bez miary wielkie peruki dam, fiszbiny, wysokie obcasy - zwłaszcza w zaawansowanej ciąży, ,sznurówki”, czyli gorsety, które zduszając piersi, powodowały problemy zdrowotne. Podobnie problemem było aż do XX w. nienoszenie majtek przez kobiety, prowadzące do ustawicznych przeziębień. Lafontaine uważał, że w naszym klimacie jest to konieczne i sytuacja będzie trwała, „póki noszenie gatek nie stanie się powszechnym między niemi zwyczajem"76. Za poradą Lafontaine'a wiele jego pacjentek „przez noszenie gatek uczyniły koniec swym cierpieniom"77.

Lekarze prowadzili następnie walkę z pijaństwem, a z kolei rzeczywiste negatywne skutki używania tytoniu nie były jeszcze znane: „Lulka toż samo jest dla mężczyzn, co wachlarz dla dam" - pisał Lafontaine „życzyłbym sobie tylko sobie odzwyczaić WMPana od palenia tytuniu zaraz po obiedzie"78. Jak pisze ten autor, palili nawet wieśniacy: „Wieśniacy przymuszeni pracować w upale na polu, gaszą sobie pragnienie lulką tytuniu"79. Wskazuje jednak, że dym wielu osobom przeszkadza, zwłaszcza damom, i w oberżach dla palaczy powinny być osobne sale.

Relacje z epoki zwykle czyniły szlachtę odpowiedzialną za stan kondycji biologicznej chłopów. Chłop pańszczyźniany miał być wymizerowany, apatyczny, otępiały, pozbawiony ludzkich uczuć, pijany, leniwy, niezdolny do jakiegokolwiek samodzielnego, energicznego działania, brudny

${ }^{75}$ H. Möller, Aufklärung in Preussen. Der Verleger, Publizist und Geschichtsschreiber, Friedrich Nicolai, Berlin 1974, s. 449-450.

${ }^{76}$ L. Lafontaine, O używaniu i nadużywaniu rzecznych, a mianowicie wiślanych kapieli i nieco o kapieli powietrznej, „Dziennik Zdrowia dla Wszystkich Stanów” 1801, 1, s. 48-53; idem, O wpływie nowych strojów damskich na ich zdrowie, „Dziennik Zdrowia dla Wszystkich Stanów" 1801, 1, s. 71-86. T. Srogosz, Trwałość i zmienność warunków zdrowotnych ludności chłopskiej, s. 92-93.

${ }^{77}$ L. Lafontaine, 0 wpływie nowych strojów damskich, s. 84.

${ }^{78}$ Idem, O paleniu tytuniu, „Dziennik Zdrowia dla Wszystkich Stanów” 1801, 5, s. $244-245$.

${ }^{79}$ Ibidem, s. 245. 
i śmierdzący. Bezmięsna i mało różnorodna dieta połączona z systemem propinacyjnym rujnowała chłopom zdrowie i w rezultacie czyniła z nich istoty mało użyteczne dla absolutystycznego państwa zarówno jako podatnicy, jak i jako rekruci. F. Herzberg podkreślał też różnicę między polskimi chłopami a sprowadzanymi przez szlachtę zamożnymi kolonistami niemieckimi. Rzadko tylko ktoś pisze, że polscy chłopi byli zdrowi, dobrze zbudowani, o białych zdrowych zębach. Tymczasem - jak uważali Prusacy - to chłop wytwarzał cały dochód narodowy, od jakości jego pracy zależeć miały wpływy podatków państwa, on też miał bronić kraju lub podbijać kraje sąsiednie. $Z$ tego względu Polska widziana była jako kraj, w którym przy republikańskim ustroju panuje jednocześnie skrajna nierówność, samowola i ucisk większości przez nielicznych, podważający bezpieczeństwo całego organizmu państwowego ${ }^{80}$.

Kwestia wyżywienia, diety, trybu i stylu życia odgrywała wówczas w ocenach lekarskich ważną rolę. Fernand Braudel pisał zasadnie: „Przez całe wieki głód powraca z taką natarczywością, że staje się częścią ustroju biologicznego ludzi, jedną ze struktur ich życia codziennego. Drożyzna i ubóstwo to zjawiska powszechne nawet w uprzywilejowanej Europie [Zachodniej - D.Ł.]. Paru aż nazbyt dobrze odżywionych bogaczy

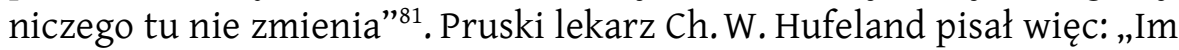
człowiek naturze i jej prawom wierniejszy jest, tym dłużej żyje [--] ludzie, którzy za młodu jarzynami żyli, a rzadko mięsa kosztowali, najdłużej żyli". Spać należało według twórcy makrobiotyki 6-8 godzin, ale nie więcej i nie mniej ${ }^{82}$. Sytuacja na początku XIX w. o tyle się poprawiała, że następowało upowszechnianie uprawy ziemniaków. W opisie powiatu babimojskiego z 1807 r. czytamy o „wielkiej obfitości” upraw ziemniaków, sprzedawanych do Wschowy i Sulechowa. Wspomina się przy tym, że ziemniak traktowany jest nadal jako uprawa ogrodowa ${ }^{83}$.

T. Srogosz pisał, że w historiografii PRL-u nie różnicowano uwarstwienia ludności chłopskiej, które było rozmaite, nie widziano różnic regionalnych i społecznych ${ }^{84}$. Dotychczasowi badacze doskonale zdawali sobie sprawę z rozwarstwienia wsi, także z tego, że przytłaczającą większość gospodarstw stanowiły w najlepszym razie jednołanowe za-

${ }^{80}$ F. Herzberg, op. cit., s. 113-116, 123; „Bericht des Officials Libor an die Kalischer Kriegs- und Domänen-Kammer”, 3 V 1799, w: Preussen und die katholische Kirche, t. 8 , oprac. H. Granier, Leipzig 1902, s. 128-131.

${ }^{81} \mathrm{~F}$. Braudel, Kultura materialna, gospodarka i kapitalizm XV-XVIII wiek, t. 1, Warszawa 1992 (oryg. franc. 1979), s. 66-67.

${ }^{82}$ Ch. W. Hufeland, Prawidła zdrowego i długiego życia, Lwów 1800, s. 6-7.

${ }^{83}$ AGAD, Komisja Rządowa Przychodów i Skarbu, Nr 804, k. 32-33.

${ }^{84}$ T. Srogosz, Trwałość i zmienność warunków zdrowotnych ludności chłopskiej, s. 86, 88. 
grody biednych chłopów poddanych, których dotykały zwykłe dla epoki przednowoczesnej częste klęski nieurodzaju i dla których mięso było świątecznym rarytasem. Gorsza jeszcze była sytuacja nie posiadających własnej ziemi zagrodników i chałupników. Grupa kmieci zamożnych, z własnymi parobkami, była stosunkowo nieliczna i to jest istota problemu. Powszechnie znany jest proces ekonomicznego rozdrobnienia własności chłopskiej i pogorszenia jakość życia włościan na skutek wojen XVII i XVIII w. - ich skutkiem stała się narastająca eksploatacja chłopów przez szlachtę, która chciała wyrównać sobie straty wojenne, dokręcając śrubę pańszczyźnianą ${ }^{85}$.

Kolejnym obszarem zapalnym postrzeganym przez Prusaków była kwestia niezwykle wysokiej śmiertelności, w tym przede wszystkim śmiertelności dzieci. Wokół dzieci też koncentrował się cały szereg działań państwa. Starano się spopularyzować szczepienia ochronne przeciwko ospie, jednemu z najistotniejszych powodów masowej śmiertelności dzieci. Jakkolwiek już przed Edwardem Jennerem pojawiły się w Anglii próby wariolizacji,Jenner ją spopularyzował (używając zamiast ospy ludzkiej ospy krowiej), po raz pierwszy stosując z powodzeniem w $1798 \mathrm{r}$.

Następnie dużą wagę przywiązywano do stanu położnictwa. Do XVIII w. ze względów obyczajowych przyjmowanie porodów było całkowicie w rękach akuszerek, które przekazywały swoją wiedzę z pokolenia na pokolenie. W epoce oświecenia były one bardzo krytykowane za przesądy i brak wiedzy ${ }^{86}$. Dopiero pod koniec XVIII w. akuszeria wkroczyła na uniwersytety, jako przedmiot wiedzy naukowej; zaczęto zakładać szpitale i kliniki położnicze oraz szkoły położnicze dla dziewcząt. W Niemczech pierwszy szpital położniczy powstał w 1751 r. w Getyndze, a w Polsce w 1780 r. w Krakowie. W berlińskim Charité oddział położniczy otwarto jednak już w 1727 r., a szkołę akuszerską w 1751 r. W praktyce jednak jeszcze długo w XIX w. uważano akuszerię za zajęcie kobiece, a lekarza wzywano tylko wtedy, kiedy potrzebne było rozwiązanie operacyjne ${ }^{87}$. Zwracano uwagę na znaczną liczbę naturalnych poronień, martwych porodów, wysoką śmiertelność okołoporodową dzieci i kobiet szczególnie w okresie połogu. Jak wspominałem, dopiero po $1793 \mathrm{r}$. zaczyna się urzędowa rejestracja zjawisk demograficznych i sprawozdawczość rządowa.

85 D. Łukasiewicz, Uwagi o położeniu chłopów, s. 303-331.

${ }^{86}$ L. Gąsiorowski, Zbiór wiadomości do historii sztuki lekarskiej w Polsce, t. 4, Poznań 1855, s. 133.

${ }^{87}$ H.-Ch. Seidel, op. cit., s. 239; E. Labouvie, Andere Umstände. Eine Kulturgeschichte der Geburt, Köln 1998; Z. Filar, Z dziejów w Polsce poglądów na zakażenie połogowe. Stanisław Witkowski i jego praca na stopień doktora medycyny, AHM 24, 1961, 4, s. 402; Z. Łapiński, Powstanie i rozwój nowoży tnego położnictwa w świecie, AHM 40,1977, 1, s. 28-30, 37. 
W 1806 r. w departamencie poznańskim na 15 tys. urodzeń 134 były martwe ${ }^{88}$. Nadzieje na zmianę złej sytuacji pokładano w kształceniu położnych, które miały wyprzeć „baby” - jak sądzono, hołdujące niezliczonym przesądom. Instytuty położnicze miały być również izbami porodowymi dla uboższych dziewcząt. Zaczynały się nowe próby rozwiązania problemu nieślubnych dzieci i nieracjonalnej regulacji urodzeń. Domy położnicze i pomoc akuszerska stwarzać miały tym kobietom wyjście $z$ niezmiernie trudnej dotąd sytuacji. $Z$ drugiej strony powstały nowe regulacje prawne, które nie tylko znosiły penalizację nieślubnej ciąży, ale też otwierały prowadzoną przez państwo kampanię oświatową na rzecz zaniechania piętnowania związków przedmałżeńskich, a zwłaszcza ich skutków, jako haniebnych. Aby jednak uchwycić problem we właściwym kontekście, należy przypomnieć o zaostrzeniu kar za ukrywanie ciąży bo każda winna była być zgłaszana władzom. Przy porodzie obligatoryjnie miała być obecna położna, tyleż dla dobra dziecka, co matki. Gdyby bowiem dziecko w trakcie porodu lub wkrótce po nim umarło, matka byłaby oskarżona o dzieciobójstwo. Podobnie zrezygnowano z barbarzyńskich kar za dzieciobójstwo i torturowania kobiet, wyeliminowano religijny kontekst procesu, jednak zarazem zwiększono opresywny nadzór, mający owe przestępstwa wyeliminować. Tak więc troska o dzieci miała też demograficzny charakter. Możemy również mówić o trosce o dzieci, kiedy wspomnimy o szczególnej wadze przykładanej do zwalczania chorób wenerycznych; jedną z nich (kiłę) nazywano w Wielkopolsce „chorobą warszawską”. Herzberg wskazywał na ogromną rolę wojen XVIII w. w jej upowszechnieniu przez żołnierzy różnych nacji ${ }^{89}$. Lafontaine pisał o tym: ,ten gorzki owoc rozpusty nie w samych tylko jak dawniej gości pałacach, ale już i biednego kmiotka w prostej jego chatce często odwiedzać przychodzi, a śmiertelny swój jad równie na bogacza, jak na nędzarza rozlewa. [--] Każdy szarlatan, mistrz lub baba przywłaszcza sobie mniemaną w leczeniu tych chorób doskonałość. $Z$ tej to przyczyny tyle ludzi bez nosa, oczu, zębów i innych członków postrzegać się zdarza" 90 .

Problem w szczególny sposób dotyczył wprawdzie domów publicznych i prostytutek, jednak upowszechniał się wskutek przenoszenia chorób wenerycznych przez wojsko i, co istotne, wiejskie mamki na dzieci. W obrębie miast zabiegi sanitarne w celu kontrolowania tego procederu

${ }^{88}$ AGAD, Biblioteka Ordynacji Zamoyskich, 96, k. 8.

${ }^{89}$ F. Schulenburg-Kehnert, Eine Denkschrift des Ministers [--] über Südpreußen, ZHGPP 9, 1894, s. 137-138; K. Kassel, Aus Preussens Sanitätsreform in Polen, „Historische Monatsblätter für die Provinz Posen” 1916, 7/8, s. 90-91; F. Herzberg, op. cit., s. 135.

${ }^{90}$ L. Lafontaine, Przedmowa. 
koncentrowały się na rejestracji domów publicznych i kobiet zajmujących się prostytucją, kontroli lekarskiej, nadzorze i wydawaniu koncesji na prowadzenie domów publicznych i stosowaniu kar pieniężnych i więzienia w wymiarze 1-2 lat za łamanie tych przepisów prawnych. Nielegalne uprawianie prostytucji karano czterotygodniowym więzieniem. Prowadzono też akcję propagandową, ostrzegając dziewczęta z małych miast i wsi, aby z żądzy łatwego zysku i pracy w wielkim mieście Berlinie nie dały się zwieść na złą drogę ${ }^{91}$.

\section{Stereotypy etniczne}

Różnego rodzaju oceny związane z poziomem sanitarnym kraju weszły jako elementy składowe do szerszych uogólnień na temat charakteru narodowego Polaków (National-Charakter) ${ }^{92}$. Jest niezwykle znamienne, że niektórzy historycy zajmujący się zagadnieniem stereotypów etnicznych ${ }^{93}$ zwykli te wypowiedzi lekceważyć, traktować je jako propagandowe inwektywy. Wypowiedzi na temat „odoru” i jego powodów traktowane są niesłusznie a priori jako naznaczone niechęcią do Polaków. Tymczasem w świetle wyobrażeń ówczesnych była to problematyka godna dyskusji i nie uważano jej za niezręczną, a z pewnością za istotną. Wypowiedzi pruskie miały przeto w znacznym stopniu charakter merytoryczny i przekładały się następnie na plany i próby podejmowania działań zaradczych.

Niewątpliwie na tle innych ziem polskich Wielkopolska i Pomorze Gdańskie, zwłaszcza zamożniejsza część Prus Królewskich, wyróżniały się korzystnie. Jadąc na wschód, jeden z autorów pisał: „coraz gorsi i mniej

91 „Verordnung wider die Verführung junger Mädchens zu Bordels und zur Verhütung der Ausbreitung wenerischer Übel", 2 II 1792, w: Novum Corpus Constitutionum Prussico-Brandenburgensium, t. 9, Berlin 1796, s. 765-776.

${ }^{92} \mathrm{~Np}$. wspomina o nim A. von Holsche, pojawia się także w urzędowej korespondencji, zob. „Immediat-Bericht der Etats Minister Wöllner und Voß”, 30 VI 1793, w: Preussen und die katholische Kirche, t. 7, oprac. M. Lehmann, Leipzig 1894, s. 52-53; por. A. Warschauer, Die deutsche Geschichtsschreibung in der Provinz Posen, Poznań 1911, s. 29.

${ }^{93}$ Do tego zagadnienia obszerna literatura dotycząca stereotypów etnicznych, zob. T. Hofman, Der radikale Wandel. Das deutsche Polenbild zwischen 1772 und 1848, „Zeitschrift für Ostforschung" 1993, z. 3, s. 358-390; S. Salmonowicz, Obraz Polski i Polaków $w$ niemieckiej opinii publicznej w latach 1795-1815, ZH 58, 1993, 4, s. 7-23; idem, Polacy i Niemcy wobec siebie. Postawy - opinie - stereotypy (1697-1815), Olsztyn 1993; idem, Jerzy Forster a narodziny stereotypu Polaka $w$ Niemczech XVIII/XIX wieku, ZH 52, 1987, 4, s. 135-147; T. Szarota, „Pole”, „Polen” $i$,polisch” $w$ słownikach niemieckich dialektów i zbiorach przysłów, Sobótka 41, 1986, 2, s. 215-242; H. Orłowski, Polnische Wirtschaft. Nowoczesny dyskurs o Polsce, Olsztyn 1998; L. Wolff, Inventing Eastern Europe: The Map of Civilization on the Mind of the Enlightenment, Stanford, Calif. 1996. 
cywilizowani ludzie". Kontrast pojawiał się przy zestawieniu Mazowsza z Wielkopolską czy ogólnie Prus Nowowschodnich i Południowych ${ }^{94}$.

Heterostereotyp jest często negatywną wypowiedzią o „innych” budowaną w opozycji do autostereotypu ${ }^{95}$. Więc jeżeli w Polsce panowała polnische Wirtschaft ${ }^{96}$, to Prusy zdaniem autorów relacji były zapewne krajem cywilizowanym. Kiedy śledzimy pruską i oświeceniową narrację o polskich stosunkach sanitarnych, aż się prosi, aby zapytać, jak dalece stereotypowe były te wypowiedzi. Przy tym jasno widać, że nakłada się tu na siebie kilka różnych stereotypów i zjawisk. Po pierwsze negatywny pruski stereotyp sąsiadów, czyli „obcych”, stereotyp polnische Wirtschaft; po drugie negatywny ogólnoeuropejski oświeceniowy stereotyp zacofanej i feudalnej Europy Wschodniej ${ }^{97}$, przy tym obydwa od siebie zależne i współdziałające; po trzecie analogiczny negatywny także oświeceniowy autostereotyp polski. Protestancka wrogość wobec katolików nakładała się tu na wrogość deistów i ludzi oświecenia. Po czwarte wreszcie świadoma pruska propaganda, dyskredytująca także przed Europą polskie elity szlacheckie jako despotów, gnębiących biednych chłopów, krytykująca panujący w Polsce bałagan, co zmierzało do wniosku, że Polacy nie są w stanie sami sobą rządzić ${ }^{98}$. Te wypowiedzi pruskie, jakkolwiek propagandowo nagłaśniane, jednak w dużym stopniu wyrażały rzeczywiste przekonanie, na co wskazują również przeanalizowane ostatnio przez Bogdana Wachowiaka testamenty Hohenzollernów, gdzie znalazła się porcja kąśliwości Fryderyka II wobec polskiej szlachty oraz negatywna ocena Polski jako kraju feudalnego ${ }^{99}$. Z drugiej strony nie powinniśmy popadać w przesadę $\mathrm{z}$ dyskredytowaniem pruskich ocen, ponieważ jakkolwiek jednostronne, jednak mówiły one wiele prawdy o stosunkach sanitarnych na ziemiach polskich. Wskazuje na to porównanie $\mathrm{z}$ badaniami historyków cywilizacji prowadzonymi na podstawie źródeł nienarracyjnych. Ostatecznie więc w odniesieniu do pruskich opinii na

${ }^{94}$ Aus dem Tagebuch eines sächsischen Offiziers i.J. 1808, oprac. P. Pietsch, „Historische Monatsblätter für die Provinz Posen"1906, 8/9, s. 120.

${ }^{95}$ H.H. Hahn, Stereotypy narodowe. Głos na rzecz historycznych badań nad stereotypami, w: idem, Stereotypy - tożsamość - konteksty. Studia nad polską i europejską historia, Poznań 2011, s. 31-70. W literaturze polskiej ciekawie o tej kwestii pisze Ludwik Stomma, Antropologia kultury wsi polskiej XIX w., Warszawa 1986, s. 5-55.

${ }^{96}$ H. Orłowski, op. cit.

${ }^{97}$ L. Wolff, op. cit.

${ }_{98}$ Zob. P. Blickle, Von der Leibeigenschaft zu den Menschenrechten. Eine Geschichte der Freiheit in Deutschland, München 2003; Historia Pomorza, red. G. Labuda, t. 2, cz. 3, Poznań 2003; Prusy w okresie monarchii absolutnej (1701-1806), red. B. Wachowiak, Poznań 2010.

${ }^{99}$ B. Wachowiak, Polska - Rzeczpospolita Obojga Narodów w testamentach politycznych Hohenzollernów XVII-XVIII w., RH 76, 2010, s. 190. 
temat włościan polskich opowiadam się raczej za poglądem Karla Poppera, który mówi o stereotypach, że dają wiedzę czasami fałszywą, czasami jednostronną, ale czasami tylko uproszczoną, które to uproszczenia są niezbędne do poruszania się w świecie ${ }^{100}$. Trzeba zwrócić uwagę - wskazuję tu na tę sprawę wielokrotnie - że oceny sytuacji sanitarno-medycznej Rzeczypospolitej już w czasach saskich i stanisławowskich były bardzo pesymistyczne. Jak pisał już W. Smoleński: „Obcy lekarz lub chirurg dość, by jedną lub dwie szczęśliwie dopełnił kuracje, jest wyrywany z rąk do rąk, chwile jego ważą na dukaty. Często ci tak wysoko cenieni lekarze są awanturnikami, którzy uczyli się wszystkiego, prócz medycyny. Szeregi ich rekrutują się niemal ze wszystkich narodowości europejskich: Anglików, Włochów, Francuzów, szczególniej zaś Niemców. Sprowadzają ich magnaci przez korespondencje na chybił trafił, przywożą z zagranicy. Czereda ta operuje bez patentów i świadectw" ${ }^{101}$. Pewne ożywienie i początek zmian przyszły w epoce stanisławowskiej. W Krakowie przed reformą kołłątajowską na uczelni pracował tylko jeden profesor medycyny. Król zażądał uniwersałem w 1784 r. i ponownie w 1785 r., aby wszystkie miasta i miasteczka wysłały uczniów na uczelnię krakowską. Powinno ich być 170 , jednak zostało to zrealizowane tylko częściowo z powodu braku środków finansowych ${ }^{102}$.

\section{Organizacja służby zdrowia} i informacji statystycznych

Rzeczą podstawową było zorganizowanie przepływu informacji o stanie kraju i jego mieszkańców, jakiego wcześniej w Polsce nie było. Służyła temu statystyka medyczna, polegająca na przekazywaniu skwantyfikowanych faktów od najniższych do najwyższych szczebli władz medycznych. Na ziemie polskie przeniesiony został z pewnymi modyfikacjami cały system pruskiej sprawozdawczości sanitarnej. 1 listopada 1793 r. zarządzono spis lekarzy i całej służby medycznej w prowincji ${ }^{103}$. Wobec powolnego sporządzania sprawozdań powtórzono polecenie 16 listopada.

Rozporządzenie z 16 listopada $1764 \mathrm{r} \cdot{ }^{104}$ nakładało wymóg prowadzenia wykazu zgonów wg ich przyczyn, tj. przede wszystkim chorób, będących

${ }^{100}$ K. Popper, Wiedza obiektywna. Ewolucyjna teoria epistemologiczna, Warszawa 1992 (oryg. ang. 1972).

${ }^{101}$ W.Smoleński, op. cit., s. 272.

${ }_{102}$ M. Hanecki, op. cit., s. 265-267; por. W. Smoleński, op. cit., s. 272-273.

${ }^{103}$ Das Jahr 1793, s. 640.

${ }^{104}$ R. Turczynowski, J. Kisielewicz, Księgi metrykalne jako źródło wiadomości o przyczynach zgonów w dawnych stuleciach, AHM 31, 1968, 2, s. 213-219. 
powodem śmierci. Pierwszy taki spis w Prusach sporządzony został w Berlinie w 1737 r., a od 1764 r. prowadzono go regularnie ${ }^{105}$. Każdorazowo przyczyna zgonu miała być potwierdzona przez lekarza. Po pierwszym rozbiorze ten sposób postępowania przeniesiono na obszar Prus Zachodnich i Dystryktu Noteckiego, a po 1793 r. do Prus Południowych ${ }^{106}$. Tutaj odpowiedzialni za sporządzanie wykazów zgonów wg chorób byli fizycy (tj. lekarze) powiatowi ${ }^{107}$. System czterech tabel populacyjnych (A-D) podawał informacje o wieku zmarłych, porze roku zgonu, liczbie zmarłych, urodzonych, małżeństw i przystępujących do komunii św., stanie cywilnym (panny, kawalerowie, wdowy, wdowcy) i wieku małżonków. W Prusach Południowych od roku 1799 przygotowywano co roku 15 grudnia sprawozdanie o stanie całej prowincji, w którym odrębna część poświęcona była sytuacji zdrowotnej, tj.: stanowi zdrowotnemu prowincji, sprawom położnictwa, chorobom bydła.

Niezależnie od tego Ober-Collegium Medicum et Sanitatis w roku 1803 zażądało odrębnych rocznych raportów z analizą chorób epidemicznych, ich topografii, środków żywienia, środków poprawy stanu zdrowotnego, śmiertelności, zarazy bydła, szczepienia przeciwko ospie ${ }^{108}$. Ze względów populacyjnych statystyką przyrostu naturalnego interesowały się również najwyższe władze. Na przykład rozkaz gabinetowy Fryderyka II z 26 grudnia 1777 r., a potem powtórnie z 11 lutego 1778 r. dopominał się od kamery w Kwidzynie wyjaśnienia powodów nadwyżki zgonów nad urodzeniami w roku 1776/1777 ${ }^{109}$.

Organizacja służby medycznej przebiegała na wzór pruski. W Prusach Zachodnich wprawdzie przystąpiono do niej już w 1772 r. ${ }^{110}$, jednak dopiero w 1776 r. po przeegzaminowaniu przed Naczelnym Kolegium Medycznym w Berlinie stanowiska objęło 11 fizyków powiatowych. W kolejnych latach obsadzono też stanowiska chirurgów powiatowych, przy czym roczne uposażenie lekarza wynosiło $150 \mathrm{rtl}$., a chirurga $50 \mathrm{rtl}$. Prowincjonalne Collegium Medicum w Kwidzynie założone zostało dopiero w 1778 r. ${ }^{111}$ Do

105 O. Behre, op. cit., s. 149.

106 Roczne tabel urodzeń, zgonów, zwartych małżeństw, przystępujących do komunii św., zob. Geheimes Staatsarchiv Preußischer Kulturbesitz w Berlinie-Dahlem (dalej: GStA PK), Gen. Dir. Westpreußen und Netzedistrikt, Tit. XLIII, Vol. 1 za lata 1773-1778. Tabele z 1799 r. nosiły nazwę „General Verzeichniß von den Copulirten, Besterben und Communicanten in Cammer Departament”.

${ }^{107}$ K. Kassel, Ein ärztliches Kulturbild aus Südpreussen, „Historische Monatsblätter für die Provinz Posen" 1915, 11/12, s. 169-170.

${ }^{108}$ J. Landsberger, op. cit., s. 322; S. Olczak, Ospa prawdziwa i szczepienie ochronne przeciw ospie w Kaliszu i na terenie Ziemi Kaliskiej, AHM 46, 1983, 3, s. 355.

109 Westpreußen unter Friedrich dem Großen, wyd. M. Bär, t. 2, Leipzig 1909, s. 366-368.

${ }_{110}$ M. Bär, Westpreußen unter Friedrich dem Großen, t. 1, Leipzig 1909, s. 497-503.

${ }^{111}$ Ibidem, t. 1, s. 500. 
tego momentu jedynie dwie pruskie prowincje nie posiadały kolegium medycznego - Wschodnia Fryzja i Prusy Zachodnie.

Dokładnie ten sam scenariusz po dwudziestu latach powtórzył się w Wielkopolsce. Po wkroczeniu na ziemie polskie władze pruskie przystąpiły do organizacji służby medycznej. Reskryptem z 15 maja 1793 r.i rozkazem gabinetowym z 30 sierpnia 1794 r. powołano w Poznaniu Collegium Medicum et Sanitatis, podporządkowane naczelnym władzom medycznym w Berlinie ${ }^{112}$. Władze prowincjonalne złożone były z dwóch przedstawicieli lekarzy, aptekarzy i chirurgów, którzy swoje funkcje pełnili społecznie. I tutaj wyznaczono fizyków i chirurgów powiatowych ze skromnym uposażeniem (100-200 rtl. ${ }^{113}$. Podobne władze powstały w pozostałych dwóch departamentach, chociaż obsada stanowisk nastręczała problemy ${ }^{114}$.Z jednej strony brakowało lekarzy cywilnych, których można by obsadzić w nowo zajętych prowincjach. Następnie w rezultacie inflacji w schyłku XVIII w. nie zmieniane od lat siedemdziesiątych wynagrodzenia lekarzy spadły do $1 / 3$ pierwotnej wartości. Przy tym wszystkim po obsadzeniu ziem polskich przez armię pruską pojawiła się spora grupa felczerów wojskowych i weteranów, którzy nielegalnie i po niższych stawkach świadczyli swoje usługi ludności. Leczeniem zajmowali się też nielegalnie kaci i położne. Mimo ogólnego braku lekarzy ich usługi nie cieszyły się wielką popularnością, co Prusacy tłumaczyli małą siłą nabywczą ludności ${ }^{115}$. Oficjalny przepis pruski z 1726 r. regulował to w ten sposób, że tylko felczerzy pułkowi mieli prawo prowadzić praktykę poza jednostką wojskową, natomiast kompanijnym było to zakazane. Władze pruskie zatrudnianie lekarzy pochodzenia żydowskiego uważały za dyskusyjne, ze względu na panujący w prowincji antysemityzm, chociaż przecież wśród praktykujących medyków Żydzi stanowili i tak znaczny odsetek ${ }^{116}$.

Kwestię zaniżonych taryf usług lekarskich Collegium Medicum odesłało do ministerstwa finansów, gdzie utonęła w powodzi pilniejszych potrzeb. Taksa za wizytę lekarską wynosiła wówczas 2-3 grosze, a jeżeli wypisywana była recepta -4 grosze. Ustalona też była taksa kosztów podróży ${ }^{117}$.

${ }^{112}$ K. Kassel, Ein ärztliches Kulturbild, s. 163; J. Landsberger, Medizinalwesen, w: Das Jahr 1793, s. 629-630, 636.

${ }^{113} \mathrm{~J}$. Landsberger, Medizinalwesen, s. 635-636.

${ }^{114}$ Medicinal Anstalten für Südpreußen, GStA PK, I HA, Rep 7c, Nr 1a, Fasz. 1, k. 248; Urkunden und Akten zur Geschichte der preußischen Verwaltung in Südpreußen und Neuostpreußen 1793-1806, wyd. W. Hubatsch, Frankfurt a.M. 1961, s. 67; K. Kassel, Ein ärztliches Kulturbild, s. 162.

115 Das Jahr 1793, s. 634-635, 639-640; K. Kassel, Ein ärztliches Kulturbild, s. 162-163.

116 Na temat rodziny Wolffów zob. J. Jacobson, Dr. A. E. Wolff, erster südpreussischer Medizinalassesor in Posen, „Historische Monatsblätter für die Provinz Posen” 1916, 3, s. 31-37.

${ }^{117}$ K. Kassel, Ein ärztliches Kulturbild, s. 167,169. 
Wg wzoru pruskiego z 1767 r. Fryderyk II w rozkazie dla Prus Zachodnich z 1774 r. zabraniał uprawiania zawodu lekarskiego osobom nie posiadającym urzędowego zezwolenia. W związku z tym w przypadku śmierci każdego pacjenta nauczyciel lub zakrystian zobligowani byli do wskazania lekarza, który sprawował nad zmarłym przed jego śmiercią opiekę, by - jeśli był to lekarz-szarlatan - można go było ukarać. Rozkaz precyzował, w jakich sytuacjach nadużywana dotąd metoda leczenia przez puszczanie krwi może być stosowana ${ }^{118}$. Podobnie wskazywał Lafontaine, że krew puszcza się albo dla mody, albo często profilaktycznie i wierzy się błędnie, iż wyleczyć można w ten sposób wszystko ${ }^{119}$.

od 1794 r. żaden lekarz na obszarze Prus Południowych nie miał prawa prowadzić praktyki nie złożywszy uprzednio egzaminu przed Collegium Medicum. Podobny przepis odnosił się do aptekarzy, chirurgów i balwierzy ${ }^{120}$. Atesty i koncesje były rzeczywiście wprowadzane: w teczce za lata 1794-1804 mamy listy lekarzy z prowincji, którzy je otrzymali ${ }^{121}$. Do 1798 r. - jak wynika z urzędowego raportu - sytuacja ogólna nie poprawiła się zasadniczo, ponieważ brakowało kandydatów na lekarzy z dyplomami i w praktyce zostawali nimi często synowie przysposobieni do wykonywania zawodu ${ }^{122}$. W okresie rządów Karla Georga Hoyma relacje bywały nieco bardziej optymistyczne - śląski minister donosił o znacznym postępie w stosunkach sanitarnych już w 1797 r. ${ }^{123}$ Chirurg warszawski Franciszek Mierczyński w 1803 r. przedkładał władzom pruskim pismo w sprawie posiadanych kwalifikacji. Tłumaczył się, że w czasach polskich przedstawianie świadectwa na papierze nie było konieczne, więc teraz nie posiada na piśmie zaświadczeń o wykonywanej wcześniej pracy i edukacji ${ }^{124}$.

W. Neugebauer ma sporo racji, gdy traktuje świat edyktów pruskich jako rzeczywistość papierową. Poza tym jednak działalność normatywna państwa na miarę ówczesnych możliwości dokonywała ogromnych zmian, zwłaszcza kiedy porównać to z sarmacką Polską. Tworzyły się instytucje, tworzyła się sieć pojęć i wyobrażeń. Edykty pełnić też miały rolę edukacyjną. W 1794 r. ogłoszono w Prusach Południowych normy

118 P. Bräuel, Preussische Aufbauarbeit im Nördlichen Westpreußen 1772-1910, „Jomsburg", 3, 1939, s. 145-146.

${ }^{119}$ L. Lafontaine, O używaniu prezerwatywów, „Dziennik Zdrowia dla Wszystkich Stanów" 1801, 1, s. 34-36.

${ }^{120}$ K. Kassel, Ein ärztliches Kulturbild, s. 153-164; J. Landsberger, Medizinalwesen, s. 632.

${ }^{121}$ AGAD, GDPP, I, 14, b.p.

122 K. Kassel, Aus Preussens sänitätsreform, s. 89-90.

${ }^{123}$ Das Jahr 1793, s. 219.

${ }^{124}$ AGAD, GDPP, VI, 3302, k. 6-9. 
dotyczące zachowań na wypadek ratowania ludzi w zagrożeniu życia ${ }^{125}$. Za dostarczenie do chirurga osoby duszącej się lub zmarzniętej przewiduje się tu 2,5 do 5 talarów nagrody, za jej uratowanie 5 lub 10 talarów. Inne obwieszczenie dotyczyło ratowania topielców, wisielców i zamarzniętych „bez różnicy stanu” ${ }^{26}$. Mówi się tutaj o walce z zabobonem, „rozumowi hańbę czyniącym". Zabobonem, który zwalczano, było stawianie topielców na głowie i toczenie po beczkach. „Można dla większego wabienia płuców dym tytoniowy dmuchać w usta" ${ }^{127}$. Propagowano równocześnie równie wątpliwe sposoby, takie jak wdmuchiwanie dymu tytoniowego w odbyt, dla uczynnienia brzucha, „do czego służy specjalna machina do wdmuchiwania dymu tytoniowego". Jeżeli jednak człowiek akurat takiej machiny przy sobie nie ma, to można wykorzystać do tego celu fajkę: „Namoczyć koniec cybucha olejem, wetknąć w zadek chorego, drugi koniec bierze człowiek w usta i wdmuchuje tam dym z innej lulki. Najskuteczniejszy jest brazylijski tytoń" 128 .

Kolejny edykt dotyczył odpowiedzialności właściciela za zachorowania psów na wściekliznę. Kiedy zauważy on u psa objawy choroby, natychmiast powinien go zabić. Jeżeli jednak ten ucieknie i narobi szkód, winowajcę czeka mandat w wysokości 20 talarów. Nadto za zastrzelenie własnego psa właściciel będzie musiał leśniczemu zapłacić dodatkowo 2 talary. Aby tego uniknąć, wszystkie psy powinny być na łańcuchach ${ }^{129}$.

\section{Próby poprawy sytuacji sanitarnej miast}

Wypada pokrótce zreferować główne posunięcia władz pruskich na poszczególnych obszarach polityki sanitarnej ${ }^{130}$. Po $1793 \mathrm{r}$. załatwiono wiele spraw związanych z porządkiem, stanem sanitarnym i bałaganem oraz oświetleniem ulic miejskich, stanem gospód oraz zagrożeniem przeciwpożarowym. W Poznaniu już Komisja Dobrego Porządku z 1780 r. zalecała stworzenie kasy przeciwpożarowej dla miasta, jednak nie zostało to zrealizowane. We Wronkach każdy właściciel płacił natomiast do takiej kasy 2 dobre grosze od komina ${ }^{131}$. Miasto miało też problem ze szwędającymi się stadami bezpańskich psów. Wszyscy właściciele mieli trzymać psy, również w nocy, na łańcuchach i miały one być odpowiednio karmione

\footnotetext{
125 AGAD, GDPP, I, 240, k. 119-120.

${ }^{126}$ Ibidem, k. 121-142.

${ }^{127}$ Ibidem.

128 Ibidem.

129 AGAD, GDPP, I, 240, k. 342-349.

130 Zob. też. D. Łukasiewicz, Modernizacja przed modernizacją, s. 53-66.

131 R. Prümers, Die Stadt Posen, I, s. 180-181.
} 
i mieć miskę z wodą. Stada zwierząt wyły po nocy - jak narzekano nieobyczajnie kopulowały w najmniej odpowiednich momentach, jak podczas dostojnych przemarszów konduktów żałobnych, i stanowiły zagrożenie dla mieszkańców. Dyrektor policji sądził, że trzeba wysłać dwóch żołnierzy, żeby wystrzelali bezpańskie psy, a nadto psy wyłapywał regularnie kat miejski ${ }^{132}$. Podobnie negatywnie wyglądały oceny warunków sanitarnych Warszawy:

Jechaliśmy w nadzwyczajnym błocie pomiędzy dwoma rzędami niskich domków; z każdego niemal wisiała wiecha słomiana, godło wyszynku wódki; przed domem był wystawiony stragan, na którym widniały śledzie, obwarzanki, wódka i inne specyały chłopskie, obok niego stała beczka soli. Żyd[zi] w pantoflach, krótkich spodniach, brudnych, połatanych pończochach, w czarnej długiej, jeszcze brudniejszej sukni [--] uwijali się koło towaru swego, zapraszali głośnym krzykiem, powracające z targu chłopstwo, które się wlokło długim szeregiem na wózkach małych, jednym koniem zaprzężonych. [- - Mijaliśmy zgraje wieśniaków takich, zapijających w owych improwizowanych szynkach, niezważających na błoto, a rodzina żydowska usługiwała im na wyskok. Dalej snuło się bydło na przedmieściu, gęsi i kaczki kąpały się w kałużach, co kilka kroków siedział dziad, śpiewający pieśni pobożne, a wyciągający skorupę żółwianą ku podróżnym ${ }^{133}$.

Według statystyki z 1797 r. na 197 ulic 98 było nadal niebrukowanych, a częściowo brukowanych 8 . W cyrkule staromiejskim sytuacja była znacznie lepsza, bo niewybrukowane były jedynie 4 ulice ${ }^{134}$. Bruki robiły jednak wrażenie fatalne. Jak pisał Friedrich Schulz, z tych wszystkich ulic „może dziesięć świetnie, może pięćdziesiąt znośnie, reszta wcale nieprzyjemnie wygląda. Większość tych ulic jest wybrukowana, jeżeli nie całkowicie, to pośrodku, ale bruk jest źle utrzymany. Podczas deszczu ulice toną w błocie, a o środkach przedsiębranych dla ich oczyszczania nie warto wzmiankować” 135 . Za brudem szła oczywiście „smrodliwa aura" stolicy, a obserwator warszawianin w 1791 r. referował, że oglądając ulicę przez okno, widzi „babę siedzącą w błocie z mąką i kartoflami, dziada w rynsztoku śpiewającego i spódniczkę grodeturową panny Marcyanny, dziegciem usmarowaną"136.

${ }^{132}$ Ibidem, s. 78-80.

${ }^{133}$ F. Gajewski, op. cit., t. 1, s. 13.

134 S. Szymkiewicz, Warszawa na przełomie XVIII i XIX wieku w świetle pomiarów i spisów, Warszawa 1959, s. 86-87.

${ }^{135}$ F. Schulz, Podróże Inflantczyka z Rygi do Warszawy i po Polsce w latach 1791-1793, Warszawa 1956, s. 58-59; por. F. Giedroyć, op. cit., s. 6-7.

${ }^{136}$ F. Giedroyć, op. cit., s. 8. 
Już przed rozbiorami intensywnie pracowała Komisja Brukowa i ulepszano kolejne ulice. Brukowano środek ulicy o szerokości 10-14 m spadziście, aby woda spływała na boki, i posypywano bruk grubo piachem, aby bruku nie naruszać. Od 1784 r. zaczęto na niektórych ulicach kłaść wąskie chodniki na wzór Zachodu (trottoary), ale były to dopiero początki. Nawet w centrum boczne ulice, a nawet Aleje Ujazdowskie, do końca stulecia nie miały bruków ${ }^{137}$. Uprzątaniem padłych psów i koni z ulic zajmował się kat, chociaż pozostawianie padliny na ulicy było zakazane i karane mandatem (a kat prawidłowo padlinę zabierać miał $\mathrm{z}$ domu) ${ }^{138}$.

Po wprowadzeniu cenzury wszystkie traktaty medyczne, zielniki, artykuły w prasie miały przed publikacją uzyskać aprobatę Collegium Medicum $^{139}$. Rozdzielono kompetencje chirurgów i lekarzy, określając w wypadku jakich chorób niezbędna jest interwencja lekarza ${ }^{140}$. Podjęto środki mające na celu sanitarną kontrolę żywności, głównie chleba i mięsa, wody, alkoholu. Chodziło głównie o ich zanieczyszczenie przez szkodliwe dla zdrowia domieszki. Historycy zwracają uwagę, że problemem była nie tyle ilość spożywanego alkoholu, ile jego zanieczyszczenia, mieszanie gorzałki z piwem i zbyt szybkie picie bez jedzenia. Bez wątpienia nadużywanie związane było z kłopotami życiowymi i gorzałkę traktowano jak pocieszycielkę $e^{141}$.

Podobne starania odnosiły się do studzien miejskich. Nie udało się Prusakom przeprowadzić do $1806 \mathrm{r}$. planowanej zamiany studzien na pompy. Zmierzano do usunięcia poza obręb miasta garbarni i rzeźni i wprowadzenia nadzoru świeżości sprzedawanego w jatkach mięsa i śledzi. Podjęto starania o odpowiedni porządek na cmentarzach. Zainteresowano się problemem bezpańskich, często wściekłych psów ${ }^{142}$. Odrębnym problemem pozostała sprawa czystości ulic. Dla zdobycia kontroli nad prostytucją wprowadzono obowiązkową rejestrację prostytutek i domów publicznych z okresowymi kontrolami lekarskimi ${ }^{143}$.

${ }^{137}$ F. de Piles, B. de Kerdu, Podróż dwóch Francuzów, w: Polska stanisławowska w oczach cudzoziemców, oprac. W. Zawadzki, t. 2, Warszawa 1963, s. 677; A. Berdecka, I. Turnau, Życie codzienne w Warszawie okresu Oświecenia, Warszawa 1969, s. 72-73; F. Giedroyć, op. cit., s. 25.

${ }^{138}$ F. Giedroyć, op. cit., s. 34.

139 K. Kassel, Ein ärztliches Kulturbild, s.165.

${ }^{140}$ Ibidem, s.169.

${ }^{141}$ T. Srogosz, Trwałość i zmienność warunków zdrowotnych ludności chłopskiej, s. 90-91; H. Biegeleisen, op. cit., s. 330-332.

${ }^{142}$ Edict wegen des Tollwerdens der Hunde für Schlesien und Südpreußen, $28 \mathrm{~V}$ 1797, AGAD, GDPP, I, k. 342-349; K. Kassel, Ein ärztliches Kulturbild, s. 170; R. Prümers, Die Stadt Posen, I, s. 185-186; idem, Die Stadt Posen in südpreussischer Zeit. II. Das Polizeiwesen, ZHGPP 23, 1908, s. 77-78; Das Jahr 1793, s. 638.

${ }^{143}$ R. Prümers, Die Stadt Posen, II, s. 117-118. 
Mimo ogólnych narzekań na stan bruków ulicznych remonty prowadzono okazjonalnie i wycinkowo. Największe szanse miały szczególnie zaniedbane ulice, którymi przejeżdżać miał król, lub te, na których doszło do niefortunnej przygody jakiegoś wysokiego urzędnika ${ }^{144}$. Znacznie pilniejsza była pomoc dla pogorzelców i odbudowa spalonych budynków. Starano się także poprawić stan sanitarny więzień i szpitali ${ }^{145}$.

Nowym zadaniem było zapewnienie odpowiednich warunków sanitarnych garnizonom wojskowym, co przy braku koszar i lazaretów oraz kiepskich warunkach mieszkaniowych nie było łatwe do zrealizowania. Na 15 tys. mieszkańców Poznania przypadało 2 tys. osób garnizonu, z czego 427 dzieci i 355 kobiet $^{146}$.W zakresie zainteresowań polityki sanitarnej znajdowały się także sprawy opieki i nadzoru nad ubogimi i żebrakami, a więc przytułki, sierocińce - były one nadzorowane przez odrębne Dyrektorium Ubogich (Armendirektorium).

W 1804 r. w Poznaniu szczepienia ochronne przeciw ospie podjął dr Francke ${ }^{147}$. Szczepiono tu nieodpłatnie każdą osobę, która się zgłosiła. Poza tym również wszyscy lekarze mieli bezpłatnie otrzymywać odeń szczepionki dla upowszechniania ich w swojej okolicy. Na przykład szczepienia dzieci w swoim majątku w Pługawicach prowadził osobiście Zerboni di Sposetti, prosząc też sąsiadów, aby wysyłali dzieci ze swoich majątków do szczepienia. W Warszawie już w 1801 r. szczepienia prowadził Jacek Dziarkowski. W Kaliszu w 1810 r. za darmo biedne dzieci zaszczepiali w formie akcji fizyk powiatowy Bednarczyk i chirurg powiatowy Leonard. Projekt ogłoszono przez obwołanie na rynku, a także z kościelnych ambon w okolicy. Starania władz pruskich datują się od opublikowania 11 lipca 1801 r. cyrkularza dla wszystkich kolegiów lekarskich dotyczącego szczepienia ospy, gdzie zachęcano do tego lekarzy. 15 lipca 1802 r. wydano podobne rozporządzenie dla Prus Nowowschodnich. W całych Prusach w 1802 r. zaszczepiono przeciw ospie ogółem 17740 osób. Starania te kontynuowane były w Księstwie Warszawskim, a za moment ważny uznać należy wprowadzenie obowiązkowych szczepień ochronnych w $1811 \mathrm{r}^{148}$

${ }^{144}$ Idem, Die Stadt Posen, I, s. 172-175; Opisy miast polskich, t. 1-2.

145 R. Prümers, Die Stadt Posen, I, s. 187-189, 192; idem, Die Stadt Posen, II, s. 102-114; J. Landsberger, Aus der Medicinalverwaltung, s. 326-327.

${ }^{146}$ H. Sommer, Posen als militärischer Standort in südpreussischen Zeit, ZHGPP 26, 1911, s. 89-99.

${ }^{147}$ R. Prümers, Die Stadt Posen, II, s. 146-148; H. Sommer, Die Verhältnisse im ehemaligen Kammerdepartament Warschau zu südpreußischer Zeit von 1795-1807, „,Deutsche Wissenschaftliche Zeitschrift für Polen" 1929, z. 15, s. 116, 120.

${ }^{148} \mathrm{~S}$. Konopka, O poczatkach szczepienia ospy krowiej na ziemiach polskich, AHM 35, 1972, 3, s. 303-308; A. M. Karaśkiewicz, Stosunki sanitarne i choroby epidemiczne w Byd- 
Po przedstawieniu ogólnie względnie optymistycznej oceny działań podejmowanych na polu polityki sanitarnej wypada nieco zróżnicować tę ocenę. Im bardziej więc oddalamy się od centrów administracyjnych ku prowincji, tym mniej różowy staje się obraz stanu faktycznego. Urzędowi lekarze nie otrzymywali wynagrodzeń, a ich kwalifikacje budziły wątpliwości ${ }^{149}$.

W trosce o zmniejszenie śmiertelności dzieci zabiegano o uporządkowanie spraw położnictwa. W Prusach Zachodnich zorganizowano instytuty położnicze w Kwidzynie i Gdańsku ${ }^{150}$. W Prusach Południowych ośrodki położnicze założone zostały w Poznaniu, Warszawie i Kaliszu ${ }^{151}$. Te starania przebiegały bardzo powoli, wśród nieustannych narzekań na brak pieniędzy. W Poznaniu mówiło się o instytucie położniczym już w 1793 r., a pierwsze kursy z 17 uczennicami w mieszkaniach prywatnych i piwiarniach odbyły się w 1799 r. Niektóre uczennice zgłaszały się na kurs tylko po to, aby przez czas jego trwania otrzymywać środki na życie. Zresztą jak się później okazało, zawód położnej w praktyce nie dawał wystarczających środków utrzymania. Za poród w Poznaniu płacono 2-4 grosze, a często do porodów położnych nie wzywano. Jeżeli chodzi o sam kurs, o zajęciach praktycznych nie było mowy, lekcje skracano do trzech dni w tygodniu po dwie godziny dziennie, stąd opinia o poziomie kursu była jak najgorsza. W 1803 r. w kursie brało udział już tylko 7 uczennic. W istocie rzeczy dopiero w 1806 r. szkoła rozpoczęła działalność we własnym budynku i w znośnych warunkach.

Jeżeli przyjrzymy się sytuacji w Prusach Południowych w okresie 1793-1806, okaże się, że poza spektakularnymi posunięciami w makroskali nie nastąpiła decydująca poprawa. Stąd jeszcze 1 marca 1805 r. minister Voß zarządzał obsadzenie stanowisk akuszerek powiatowych (Kreishebammen), które miały być wynagradzane pensją w wysokości $25 \mathrm{rtl}$. z wymogiem posiadania wykształcenia zdobytego w instytucie położniczym w Poznaniu lub Kaliszu ${ }^{152}$.

goszczy w latach 1801-1840, „Archiwum Historii i Filozofii Medycyny”, t. 16, 1936, s. 78; A. Jonecko, U. Jonecko, Pruski regulamin o szczepieniu ospy ochraniającej, wydany w roku 1803 w języku polskim, AHM 35, 1972, 3, s. 285-302; M. Łyskanowski, Zapomniany spór na temat szczepienia ospy w Warszawie, AHM 38, 1975, 2, s. 179-186; S. Olczak, op. cit., s. 359.

${ }^{149}$ H. Hockenbeck, Die Stadt Wongrowitz in südpreußischer Zeit,ZHGPP 8, 1893, s. 251-306.

150 J. Bitkowski, Położnictwo w Gdańsku od XVI do końca XIX wieku, AHM 30, 1967, 2, s. 175.

151 D. Łukasiewicz, Szkoły położnicze, w: idem, Szkolnictwo w Prusach Południowych (1793-1806) w okresie reform oświeceniowych, Poznań-Warszawa 2004, s. 231-237; idem, Szkolnictwo położnicze pod zaborem pruskim jako nowe zjawisko w służbie zdrowia i szkolnictwie na przełomie XVIII i XIX w., ,Biuletyn Historii Oświaty”, w druku.

${ }_{152}$ J. Landsberger, Aus der Medicinalverwaltung, s. 326-327; R. Prümers, Die Stadt Posen, II, s. 102-114. 
Po III rozbiorze i utworzeniu Prus Nowowschodnich (Neuostpreussen) władze pruskie podjęły tam podobne działania jak w pozostałych polskich prowincjach. I w tym wypadku jednak ich skuteczność przy szczupłości środków mogła być tylko ograniczona. Każdy powiat - podobnie jak w Prusach Południowych - otrzymał fizyka powiatowego. W 1806 r. w całej prowincji było zaledwie 17 urzędowo zaaprobowanych lekarzy, 87 szpitali i 4 zakłady położnicze. W 1806 r. zaplanowano w Białymstoku utworzenie instytutu szczepień przeciwko ospie.

Jeżeli moglibyśmy oceniać w sposób wymierny zasięg działań władz pruskich w zakresie poprawy stanu sanitarnego Wielkopolski, okazałoby się, że wyasygnowały one na politykę sanitarną nieznaczną w sumie kwotę 23,1 tys. rtl., odrębnie jednak liczono 7 tys. rtl. na utrzymanie lazaretów, 10 tys. na wsparcie miejskich kas policyjnych, 1,7 tys. na pomoc ubogim $^{153}$. Stąd nie mogło być mowy o jakimś wielkim postępie w stosunku do roku 1793, jednak zmiany były i czasy Księstwa Warszawskiego przyniosły ich kontynuację.

Przy poszukiwaniu punktów odniesienia dla ocen pruskich warto wskazać, że władze również w rdzennych pruskich prowincjach posługiwały się podobnym językiem, odnajdywały podobne problemy i ostatecznie z surowych ocen w odniesieniu do stanu sanitarnego ziem polskich nie wynika, że był on rażąco gorszy niż w prowincjach pruskich. Dla ilustracji można wskazać choćby pismo kamery królewieckiej na temat możliwych posunięć w celu poprawy sytuacji sanitarnej w Prusach Wschodnich. Wspomina się tu, że przyrost naturalny jest powstrzymywany przez niewiedzę i brak wykształcenia akuszerek, z czego wziął się postulat założenia instytutu położniczego w Królewcu. Wspominano, że korzystne byłoby założenie również instytutu szczepień przeciw ospie. Jak fatalnie, przy braku kanalizacji, przedstawiał się stan czystości Paryża, wskazuje monografia Alaina Corbin, a przecież Paryż był w tym czasie stolicą cywilizacji europejskiej ${ }^{154}$.

Jeżeli więc można by w odniesieniu do ziem polskich, które znalazły się pod zarządem pruskim, coś uznać za kluczowe, to zainicjowanie pewnych ram prawnych, instytucjonalnych i finansowych właściwych nowoczesnemu państwu, wskazanie kierunków rozwoju i realizowanie ich $\mathrm{z}$ nieco większym przekonaniem niż to odbywało się dotąd.

${ }_{153}$ A. Simsch, op. cit., s. 244-247; Das Jahr 1793, s. 196-199, 308-309.

${ }_{154}$ A. Corbin, Pesthauch und Blütenduft. Eine Geschichte des Geruchs, Frankfurt a.M. 1988 (oryg. franc. 1982). 


\section{From the History of the Sanitary Policy in the Prussian Partition Areas 1772-1807}

The great modernisation of the health service and medicine at the turn of the nineteenth century was connected, on the one hand, with scientific innovations (Pasteur, Koch) and, on the other hand, with the development of the health service and the hospital system, together with the introduction of health insurance and funds (Germany, 1883). These transformations, however, had already been initiated on a more modest scale a century earlier. In the Prussian partition area (Western, Southern, and New Eastern Prussia) the sluggish reforms of the Stanisław August Poniatowski era were continued by the much more energetic Prussian authorities, whose experiences dated to the reign of Frederick William I and even the Great Elector. The age of epidemics signified the unconditional necessity of going beyond individual health care and embarking upon activity described as "the medical police". The Prussians were engaged in modernisation rather than colonisation (i.e. exploitation), albeit a number of aspects proved unfavourable for the Poles, e.g. the imposition of the Prussian elites of power and intellectual life as a well as the medical administration apparatus. The Prussian authorities initiated the establishment of a system of obtaining information extensive demography and health (statistics of the reasons for death), which subsequently made it possible to undertake prevention. The prime cause of deaths was pox, and the range of the ensuing inoculation campaign (continued in the Duchy of Warsaw) was limited. Only the introduction in Prussia of mandatory inoculations after 1870 immediately liquidated mass-scale deaths due to this disease. Characteristics of the province indicated an extremely unsatisfactory health, sanitary, and hygiene situation. The reports contain numerous critical remarks about the health and mortality of Polish peasants, although prevailing problems in Prussia itself were identical, as was the structure of deaths. The authorities conducted a battle against folk medicine, charlatans, swindlers, and so-called unconventional medicine. For propaganda reasons the Prussians readily accentuated the Catholic nature of folk medicine (holy relics, pilgrimages, etc.), with the Prussian elites being markedly pro-Enlightenment. Quacks and female healers offered, however, the sole form of health care addressed to the peasants; physicians occurred only in the towns and treated the more prosperous members of the population, albeit those providing aid to the poor and official medical doctors also practised.

Translated by Aleksandra Rodzińska-Chojnowska 